\begin{tabular}{l|l|l|}
\cline { 3 - 3 } CRITICAL & $\begin{array}{l}\text { Western Ghats } \\
\text { EARTNERSTEM FUND }\end{array}$ \\
Special Series
\end{tabular}

\title{
RAORCHESTES GHATEI, A NEW SPECIES OF SHRUB FROG (ANURA: RHACOPHORIDAE) FROM THE WESTERN GHATS OF MAHARASHTRA, INDIA
}

\author{
Anand D. Padhye ${ }^{1}$, Amit Sayyed ${ }^{2}$, Anushree Jadhav ${ }^{3} \&$ Neelesh Dahanukar ${ }^{4}$ \\ ${ }^{1,3}$ Department of Zoology, MES's Abasaheb Garware College, Pune, Maharashtra 411004, India \\ ${ }^{2}$ Wildlife Protection and Research Society, 40 Rajaspura Peth, Satara, Maharashtra 415001, India \\ ${ }^{4}$ Indian institute of Science Education and Research, Dr. Homi Bhabha Road, Pashan, Pune, Maharashtra 411008, India \\ ${ }^{4}$ Zoo Outreach Organization, 96 Kumudham Nagar, Villankurittchi Road, Coimbatore, Tamil Nadu 641035, India \\ ${ }^{1}$ anand.padhye@mesagc.org (correspondence author), ${ }^{2}$ amitsayyedsatara@gmail.com, ${ }^{3}$ anushreejadhav@gmail.com, \\ ${ }^{4}$ n.dahanukar@iiserpune.ac.in
}

\begin{abstract}
A new species of shrub frog Raorchestes ghatei is described from the Western Ghats of Maharashtra. The species differs from its congeners based on a combination of characters including small to medium-sized adult males, snout mucronate in dorsal view, canthus rostralis angular and sharp, snout slightly projecting beyond mouth ventrally, tympanum indistinct and one third of the eye diameter, tongue without papilla but with a lingual pit, nuptial pad rudimentary to absent, a bony tubercle on humerus at the end of deltoid ridge present in males and absent in females, skin finely granulated or smooth dorsally, lateral side marbled with white blotches on brown to black background. Molecular phylogeny based on 16S rRNA gene sequence suggests that the new species is genetically distinct and forms a monophyletic clade within Raorchestes. The species exhibits sexual dimorphism with males having single sub-gular vocal sac and a tubercle on the humerus while females lack them. The species shows direct development. The species is widely distributed in the Western Ghats of Maharashtra.
\end{abstract}

Keywords: Biodiversity hotspot, bony tubercle, molecular phylogeny, new species, Raorchestes.

DOI: http://dx.doi.org/10.11609/JoTT.o3702.4913-31 | ZooBank: urn:Isid:zoobank.org:pub:F43734EB-1B67-48FC-949A-77DD7507056D

Editor: Anonymity requested.

Date of publication: 26 November 2013 (online \& print)

Manuscript details: Ms \# 03702 | Received 09 July 2013 | Final received 12 November 2013 | Finally accepted 13 November 2013

Citation: Padhye, A.D., A. Sayyed, A. Jadhav \& N. Dahanukar (2013). Raorchestes ghatei, a new species of shrub frog (Anura: Rhacophoridae) from the Western Ghats of Maharashtra, India. Journal of Threatened Taxa 5(15): 4913-4931; http://dx.doi.org/10.11609/JoTT.o3702.4913-31

Copyright: (C) Padhye et al. 2013. Creative Commons Attribution 3.0 Unported License. JoTT allows unrestricted use of this article in any medium, reproduction and distribution by providing adequate credit to the authors and the source of publication.

Funding: This work was partially supported by DST-INSPIRE Research Grant [IFA12-LSBM-21] to Neelesh Dahanukar.

Competing Interest: The authors declare no competing interests. Funding sources had no role in study design, data collection, results interpretation and manuscript writing.

Author contributions: ADP, AS, AJ and ND performed field studies. ADP and AJ performed morphometry. ADP, AJ and ND studied the type and comparative material. ND perfoemed statistical and molecular analysis. ADP and ND wrote the paper.

Author Details: ANAND D. PADhye is an Associate Professor in Zoology, Abasaheb Garware College, Pune. He works on systematics, ecology, diversity, distribution and evolution of amphibians. AMIT SAYYED is a naturalist working in Satara. He is interested in wildlife conservation, awareness, photography and research. ANUSHREE JADHAV has completed her Master of Science in Biodiversity and is interested in studying batrachology. NEELESH DAHANUKAR works in ecology and evolution with an emphasis on mathematical and statistical analysis. He is also interested in taxonomy, distribution patterns and molecular phylogeny.

Acknowledgements: Anand Padhye is thankful to Nilesh Rane and Vivek Gaur-Broome for their help during the first collection of the female specimen of this species in July 2002. Amit Sayyed is thankful to Datta Chawhan, Jitendra Patole, Akshay Bhagwat, Shriniwas Bhujbal, Abhijit Nale, Harshal Bhosle and Mujahid Shaikh, the members of WLPRS for their valuable help in the fieldwork. We also thank Mandar Paingankar, Satish Pande, Sanjay Khatavkar, Rajgopal Patil, Nikhil Modak, Sheetal Shelke, Sushil Chikne, Amod Zambre, Abhijeet Bayani, Pracheta Rana, Rohan Pandit, Rohan Naik and Vedant Dixit for their help in field work. We thank Ashok Captain for the help in photography. We are grateful to Dr. Asad Rahmani, Director; Dr. Deepak Apte, COO; Rahul Khot, incharge Natural History Collection department; Reshma Pitale, researcher and Vithoba Hegde, senior field assistant, for their help during study of the museum specimens and registration of specimens in Bombay Natural History Society, Mumbai. We thank the Director, Zoological Survey of India; Dr. K.A. Subramanian and Dr. Kaushik Deuti (Officerin-charge, Amphibia Section, ZSI, Kolkata) for providing the photographs of the type specimen. We also thank Dr. P.S. Bhatnagar, officer-in-charge, and Dr. Shrikant Jadhav, ZSI, Western Regional Center, Pune, for their help in registering specimens in ZSI-WRC. Keerthi Krutha helped in molecular work and registration of specimens in the Wildlife Information Liaison Development Museum, Coimbatore. We are grateful to the principal, Abasahab Garware College, Head Department of Zoology and Biodiversity, Abasaheb Garware College and Indian Institute of Science Education and Research, Pune for providing infrastructure facilities.

The publication of this article is supported by the Critical Ecosystem Partnership Fund (CEPF), a joint initiative of l'Agence Française de Développement, Conservation International, the European Commission, the Global Environment Facility, the Government of Japan, the MacArthur Foundation and the World Bank. 


\section{INTRODUCTION}

The Western Ghats of India harbors a rich diversity of amphibians with high levels of endemism (Dinesh \& Radhakrishnan 2011). With recent descriptions of several new species and genera of amphibians from the Western Ghats (Biju et al. 2011; Zachariah et al. 2011; Seshadri et al. 2012; Abraham et al. 2013), it is clear that the amphibian diversity within this region is subject to Linnean shortfall, where several species are not yet formally described (Bini et al. 2006), and detailed surveys and studies are essential to overcome it.

In the Western Ghats, tree frogs of the family Rhacophoridae are grouped under seven genera, namely Beddomixalus Abraham et al., 2013, Ghatixalus Biju, Roelants \& Bossuyt, 2008, Mercurana Abraham et al., 2013, Polypedates Tschudi, 1838, Pseudophilautus Laurent, 1943, Raorchestes Biju et al., 2010 and Rhacophorus Kuhl \& Van Hasselt, 1822. The genus Raorchestes was recently erected to accommodate a monophyletic clade of shrub frogs characterized by adult snout-vent length between 15 and $45 \mathrm{~mm}$, vomerine teeth absent, large gular pouch transparent while calling, nocturnal habit and direct development without free-swimming tadpoles (Biju et al. 2010). Currently, 49 species are recognized under Raorchestes by Frost (2013) and the genus is distributed in Western Ghats, southern China, Laos and Vietnam (Biju et al. 2010).

Annandale (1919) described Ixalus bombayensis (= Raorchestes bombayensis) from Castle Rock and mentioned that the species is also present in Khas (= Kaas) in Satara and Khandalla (= Khandala) in Poona (= Pune). In this communication, based on morphological and molecular analysis, we describe a new species of shrub frog and show that the populations of the Raorchestes from Satara District and Pune District, earlier reported as $R$. bombayensis are those of the new species. We further show that the character of tubercle on the humeral bone, which was previously thought as a specific character of $R$. tuberohumerus (Kuramoto \& Joshy, 2003), is a sexually dimorphic character possessed by males but not by females.

\section{MATERIALS AND METHODS}

\section{STUDY AREA}

The Western Ghats of Maharashtra state extend from south of Amboli to north of Surgana covering around $600 \mathrm{~km}$ of mountain ranges, parallel to the Arabian Sea coast, extending east as well as west, at some places even up to the seashore. A formation of a series of 200 $300 \mathrm{~m}$ high cliffs, which extends almost throughout the length of this part of the Western Ghats, forms a hurdle in the way of southwestern monsoon clouds. This results in a very high rainfall (average $6,000 \mathrm{~mm}$ ), with some places like Tamhini, Mahabaleshwar and Bhimashankar receiving rainfall up to $10,000 \mathrm{~mm}$. The major habitat in this part of Western Ghats is scrub and grasslands, both at the foothills and on the mountaintops. The hilly regions show some primary evergreen forest patches and comparatively more secondary evergreen and moist deciduous forests. The Western Ghats of Maharashtra is rich in biodiversity especially in that of amphibians (Padhye \& Ghate 2002).

Specimens of the new species of Raorchestes were collected from the northern Western Ghats at Chalkewadi $\left(17.59^{\circ} \mathrm{N} \& 73.84^{\circ} \mathrm{E}, 1082 \mathrm{~m}\right)$, plateau near Patan $\left(17.45^{\circ} \mathrm{N} \& 73.83^{\circ} \mathrm{E}, 1072 \mathrm{~m}\right)$, Jaichiwadi $\left(17.42^{\circ} \mathrm{N}\right.$ \& $\left.73.85^{\circ} \mathrm{E}, 1005 \mathrm{~m}\right)$, Thoseghar $\left(17.60^{\circ} \mathrm{N} \& 73.85^{\circ} \mathrm{E}\right.$, $1000 \mathrm{~m})$, Kaas $\left(17.70^{\circ} \mathrm{N} \& 73.82^{\circ} \mathrm{E}, 1183 \mathrm{~m}\right)$ in Satara District and Dongarwadi $\left(18.48^{\circ} \mathrm{N} \& 73.42^{\circ} \mathrm{E}, 611 \mathrm{~m}\right)$, Mulshi $\left(18.52^{\circ} \mathrm{N} \& 73.52^{\circ} \mathrm{E}, 658 \mathrm{~m}\right)$ and Taleghar near Bhimashankar $\left(19.08^{\circ} \mathrm{N}\right.$ \& $\left.73.64^{\circ} \mathrm{E}, 1025 \mathrm{~m}\right)$ in Pune District, Maharashtra, India. A total of 22 specimens were collected (nine males and 13 females). Six specimens (four males and two females) of Raorchestes bombayensis (Annandale, 1919) were collected from the type locality at Castle Rock $\left(15.395^{\circ} \mathrm{N} \& 74.337^{\circ} \mathrm{E}\right.$, $577 \mathrm{~m})$. Collected specimens are deposited in the museum collection of Bombay Natural History Society (BNHS), Mumbai; Zoological Survey of India-Western Regional Center (ZSI-WRC), Pune; Wildlife Information Liaison Development (WILD) Society, Coimbatore and Abasaheb Garware College-Zoology Research Laboratory (AGCZRL), Pune.

\section{MORPHOMETRY}

Measurements were taken to the nearest $0.1 \mathrm{~mm}$ using a digital caliper and using a binocular microscope. The following measurements, as defined by Biju \& Bossuyt (2009), were taken: snout-vent length (SVL); head length $(\mathrm{HL})$; head width $(\mathrm{HW})$; rear of the mandible to the nostril $(\mathrm{MN})$; rear of the mandible to the anterior orbital border of the eye (MFE); rear of the mandible to the posterior orbital border of the eye (MBE); snout length (SL); eye length (EL); inter upper eyelid width (IUE); maximum upper eyelid width (UEW); internal front of eyes (IFE); internal back of eyes (IBE); forelimb length (FLL); hand length ( $\mathrm{HAL})$; third finger length (TFL); disc width on finger III (FDIII); width of finger III (FWIII); shank length (ShL); thigh length ( $T L$ ); foot length 
(FOL); distance from the heel to the tip of the fourth toe (TFOL). Tympanum diameter was measured both vertically (TYDV) and horizontally (TYDH).

\section{OSTEOLOGY}

Two specimens WILD-13-AMP-104 (female) and WILD-13-AMP-105 (male) were used for osteological study following clearing and staining procedure described by Potthoff (1984).

\section{GeNETIC ANALYSIS}

Muscle tissue was harvested from nine fresh specimens of the new species (ZSI-WRC A/1484; WILD13-AMP-080, 100, 104, 105; AGCZRL-Amphibia-125, 127 $128,130)$ collected from different localities and three specimens of $R$. bombayensis (WILD-13-AMP-230, 231; AGCZRL-Amphibia-172) collected from the type locality of the species and was preserved in absolute ethanol. The tissue was digested at $55^{\circ} \mathrm{C}$ for two hours using the STE buffer $(0.1 \mathrm{M} \mathrm{NaCl}, 0.05 \mathrm{M}$ Tris- $\mathrm{HCl}, 0.01 \mathrm{M}$ EDTA, $1 \%$ SDS) with $15 \mu \mathrm{l}$ proteinase $\mathrm{K}(20 \mathrm{mg} / \mathrm{ml})$ per $500 \mathrm{ml}$ of STE buffer. DNA was extracted using conventional phenol-chloroform method and re-suspended in nuclease free water. Polymerase chain reaction was performed to amplify partial 16S rRNA gene using primer pair 16SF (5'-CGC CTG TTT ATC AAA AAC AT-3') and 16SR (5'-CCG GTC TGA ACT CAG ATC ACG T-3') (Palumbi et al. 2002). PCR reaction was performed in a $25 \mu$ l reaction volume containing $5 \mu \mathrm{l}$ of template DNA ( 200ng), $5 \mu \mathrm{l}$ of $5 X$ reaction buffer $(100 \mathrm{mM}$ Tris $\mathrm{pH} 9.0,500 \mathrm{mM} \mathrm{KCl}$, $15 \mathrm{mM} \mathrm{MgCl}_{2}, 0.1 \%$ Gelatin), $3 \mu$ of $25 \mathrm{mM} \mathrm{MgCl}_{2}, 1 \mu \mathrm{l}$ of $10 \mathrm{mM}$ dNTPs, $1 \mu \mathrm{l}$ of each primer, $0.5 \mu \mathrm{l}$ Taq polymerase (Promega) and $8.5 \mu \mathrm{l}$ nuclease free water. The thermal profile was $10 \mathrm{~min}$ at $95^{\circ} \mathrm{C}$, and $35 \mathrm{cycles}$ of $1 \mathrm{~min}$ at $94^{\circ} \mathrm{C}$, $1 \mathrm{~min}$ at $50^{\circ} \mathrm{C}$ and $2 \mathrm{~min}$ at $72^{\circ} \mathrm{C}$, followed by extension of $10 \mathrm{~min}$ at $72^{\circ} \mathrm{C}$. Amplified DNA fragments were purified using the 'Promega Wizard Gel and PCR clean up' system and sequenced. The purified PCR products were sequenced using $A B I$ prism 3730 sequencer (Applied Biosystems, USA) and Big dye terminator sequencing kit (ABI Prism, USA). Sequences were analyzed by BLAST tool (Altschul et al. 1990). These sequences have been deposited in GenBank (accession numbers are provided in Appendix A).

We retrieved additional sequences on other related species from NCBI GenBank database (http://www.ncbi. nlm.nih.gov/) details of which are provided in Appendix A. Gene sequences were aligned using MUSCLE (Edgar 2004). Best fit model for nucleotide substitution was selected from 24 models available in MEGA 5 (Takamura et al. 2011) based on minimum Akaike Information
Criterion (AIC) value (Posada \& Crandall 2001). Maximum Parsimony analysis was performed in MEGA 5. General time reversal nucleotide substitution model with gamma distribution ( $G T R+G)$, obtained as a best fit model in the model test ( $\mathrm{AIC}=4653.9, \mathrm{InL}=-2204.2$ ), was used for constructing phylogenetic tree based on maximum likelihood method in MEGA 5 and Bayesian analysis using MrBayes (Huelsenbeck \& Ronquist 2001) integrated in TOPALi v2.5 (Milne et al. 2004). Reliability of the phylogenetic tree using maximum likelihood method was estimated using bootstrap values run for 1000 iterations. For Bayesian analysis two runs were performed for 1,000,000 generations with sample frequency of 10 and burn percentage of 25 .

\section{STATISTICAL ANALYSIS}

Statistical analysis of the morphometric data was performed on size adjusted measurements by taking all measurements as percent of SVL. For analysis, we used the morphometry of related species Raorchestes bombayensis and $R$. tuberohumerus given by Biju \& Bossuyt (2009) and data collected in the present study. Multivariate normality of the data was checked using Doornik \& Hansen (2008) omnibus. Multivariate Analysis of Variance/Canonical Variates Analysis (MANOVA/CVA) was performed to understand whether related species of Raorchestes form significantly different clusters (Huberty \& Olejnik 2006). We performed Pillay's trace statistic to find the significant difference between the clusters (Harris 2001). Statistical analysis was performed in PAST (Hammer et al. 2001).

\section{RESULTS}

Raorchestes ghatei sp. nov.

(Images 1, 2a, 2d, 2g, 5a, 6)

urn:Isid:zoobank.org:act:44621AF1-15D8-44AB-8246-676470B541F8

\section{TYPE MATERIAL}

Holotype: BNHS 5579, 23.viii.2012, male, SVL $22.0 \mathrm{~mm}$, Chalkewadi $\left(17.59^{\circ} \mathrm{N} \& 73.84^{\circ} \mathrm{E}, 1082 \mathrm{~m}\right)$, Satara, Maharashtra, India, coll. A.D. Padhye, N. Dahanukar and A. Sayyed.

Allotype $^{1}$ : BNHS 5582, female, SVL $25.5 \mathrm{~mm}$, Kaas $\left(17.70^{\circ} \mathrm{N} \& 73.82^{\circ} \mathrm{E}, 1183 \mathrm{~m}\right)$, Satara, Maharashtra, India, coll. A. Sayyed, 1.viii.2012.

${ }^{1}$ According to ICZN (Rec. 72A), allotype is a designated specimen (among paratypes) belonging to the opposite sex of the holotype and the term has no name bearing function and is not regulated by the code. In the absence of a female from the same locality as that of the holotype, we have designated an allotype from one of the paratypes collected from a nearby area (15km linear aerial distance) 

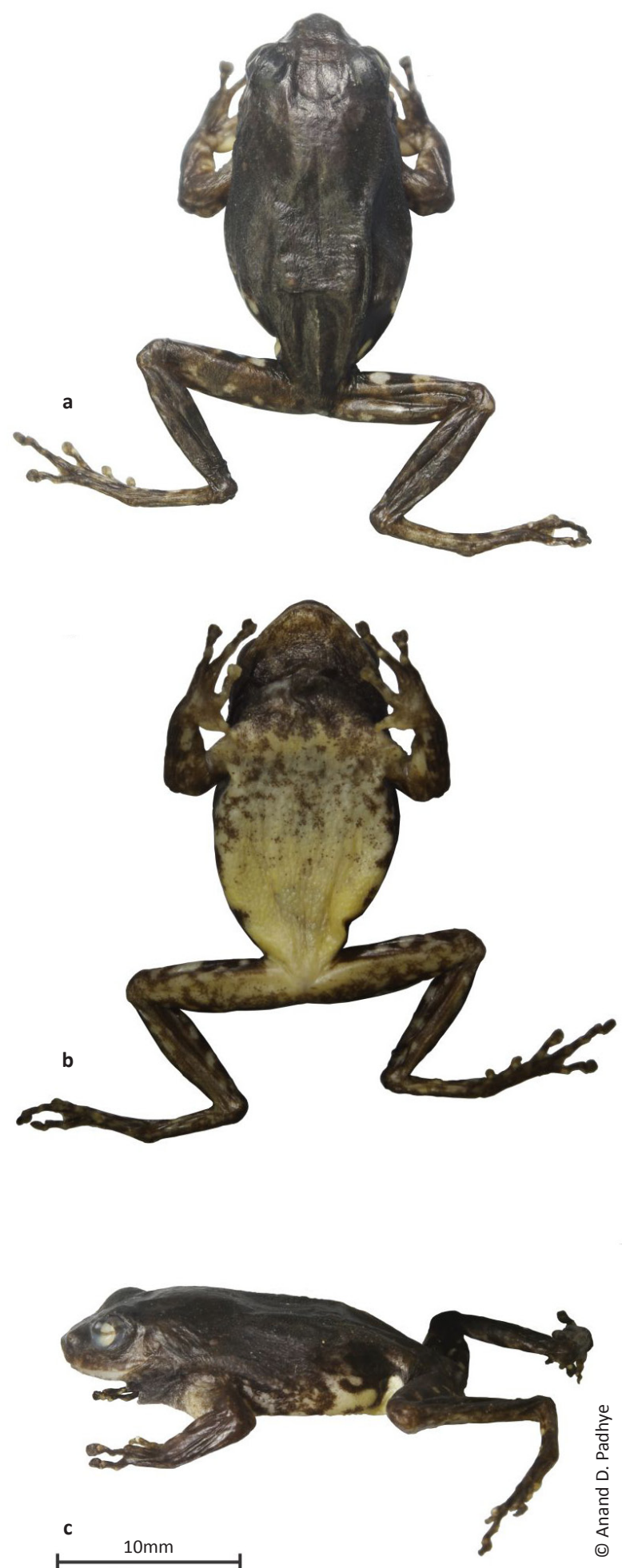

Image 1. Raorchestes ghatei sp. nov. (holotype BNHS 5579) a - dorsal view; b - ventral view; c - lateral view.

Paratypes (8 males and 12 females): BNHS 5580, 23.viii.2012, 1 male, SVL $24.3 \mathrm{~mm}$, Chalkewadi $\left(17.59^{\circ} \mathrm{N}\right.$ \& $\left.73.84^{\circ} \mathrm{E}, 1082 \mathrm{~m}\right)$, Satara, Maharashtra, India, coll.
A.D. Padhye, N. Dahanukar and A. Sayyed; BNHS 5581, 23.viii.2012, 1 male, SVL $25.5 \mathrm{~mm}$, Jaichiwadi $\left(17.42^{\circ} \mathrm{N}\right.$ \& $\left.73.85^{\circ} \mathrm{E}, 1005 \mathrm{~m}\right)$, Patan, Maharashtra, India, coll. A.D. Padhye, N. Dahanukar and A. Sayyed; ZSI-WRC A/1485, 09.viii.2012, 1 male, SVL $21.9 \mathrm{~mm}$, Dongarwadi $\left(18.48^{\circ} \mathrm{N}\right.$ \& $\left.73.42^{\circ} \mathrm{E}, 611 \mathrm{~m}\right)$, Mulshi, Pune, Maharashtra, India, coll. A.D. Padhye; ZSI-WRC A/1484, 19.ix.2011, female, SVL $20.7 \mathrm{~mm}$, Mulshi $\left(18.52^{\circ} \mathrm{N} \& 73.52^{\circ} \mathrm{E}, 658 \mathrm{~m}\right)$, Pune, Maharashtra, India, A.D. Padhye; WILD-13-AMP-078 to 080, 02.iii.2013, 3 females, SVL 15.4-21.6 mm, Taleghar near Bhimashankar $\left(19.08^{\circ} \mathrm{N} \& 73.64^{\circ} \mathrm{E}, 1025 \mathrm{~m}\right)$, Junnar, Maharshtra, India, coll. N. Modak; WILD-13-AMP-100, 16.ix.2011, 1 male, SVL 19.9mm, plateau near Patan $\left(17.45^{\circ} \mathrm{N} \& 73.83^{\circ} \mathrm{E}, 1072 \mathrm{~m}\right)$, Maharashtra, India, coll. A.D. Padhye, N. Dahanukar and M. Paingankar; WILD13-AMP-101 and 102, 2 females, 07.vii..2010, SVL 23.4-29.8mm, plateau near Patan $\left(17.45^{\circ} \mathrm{N} \& 73.83^{\circ} \mathrm{E}\right.$, $1072 \mathrm{~m})$, Maharashtra, India, coll. N. Dahanukar and M. Paingankar; WILD-13-AMP-103, 13.vi.2013, 1 male, SVL $19.1 \mathrm{~mm}$, Taleghar near Bhimashankar $\left(19.08^{\circ} \mathrm{N}\right.$ \& $\left.73.64^{\circ} \mathrm{E}, 1025 \mathrm{~m}\right)$, Junnar, Maharashtra, India, coll. A. Jadhav; WILD-13-AMP-104, 01.viii.2012, 1 female, SVL $22.7 \mathrm{~mm}$, Kaas $\left(17.70^{\circ} \mathrm{N} \& 73.82^{\circ} \mathrm{E}, 1183 \mathrm{~m}\right)$, Satara, Maharashtra, India, coll. A. Sayyed; WILD-13-AMP-105, 1.viii.2012, 1 male, SVL $19.5 \mathrm{~mm}$, Kaas $\left(17.70^{\circ} \mathrm{N}\right.$ \& $\left.73.82^{\circ} \mathrm{E}, 1183 \mathrm{~m}\right)$, Satara, Maharashtra, India, coll. A. Sayyed; AGCZRL Amphibia 123, 14.viii.2011, 1 female, SVL $28.9 \mathrm{~mm}$, Kaas $\left(17.70^{\circ} \mathrm{N} \& 73.82^{\circ} \mathrm{E}, 1183 \mathrm{~m}\right)$, Satara, Maharashtra, India, coll. A. Sayyed; AGCZRL Amphibia 125, 127 and 128, 17.ix.2011, 3 females, SVL 16.7-18.7 $\mathrm{mm}$, Thoseghar $\left(17.60^{\circ} \mathrm{N} \& 73.85^{\circ} \mathrm{E}, 1000 \mathrm{~m}\right)$, Satara, Maharashtra, India, coll. A.D. Padhye, N. Dahanukar and M. Paingankar; AGCZRL Amphibia 130, 16.ix.2011, 1 female, SVL $16.7 \mathrm{~mm}$, plateau near Patan $\left(17.45^{\circ} \mathrm{N}\right.$, $\left.73.83^{\circ} \mathrm{E}, 1072 \mathrm{~m}\right)$, Maharashtra, India, coll. A.D. Padhye, N. Dahanukar and M. Paingankar; AGCZRL Amphibia 167 and 168, 2 males, SVL 21.9 and $21.6 \mathrm{~mm}$ respectively, 13.vi.2013, Taleghar near Bhimashankar $\left(19.08^{\circ} \mathrm{N}\right.$ \& $\left.73.64^{\circ} \mathrm{E}, 1025 \mathrm{~m}\right)$, Junnar, Maharashtra, India, coll. A. Jadhav.

\section{DIAGNOSIS}

Raorchestes ghatei sp. nov. can be distinguished from all related taxa by following combination of characters: (1) small to medium sized adult males (19.1-25.5 mm SVL); (2) snout mucronate in dorsal view; (3) canthus rostralis angular and sharp; (4) snout slightly projecting beyond mouth ventrally; (5) tympanum small, indistinct in live specimens but may appear distinct in specimens stored in absolute ethanol, tympanum diameter is almost one-third of the eye diameter; (6) tongue without 

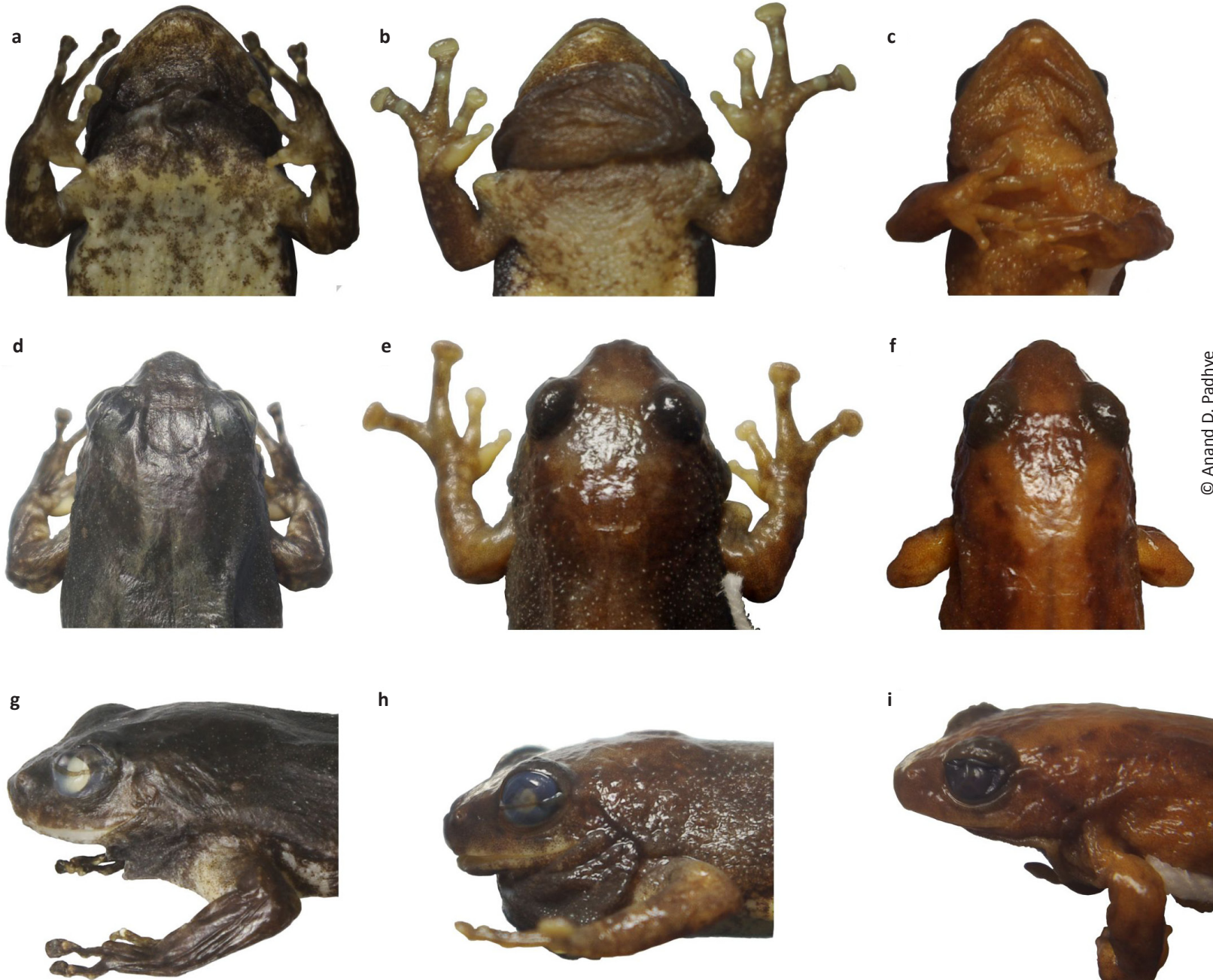

h

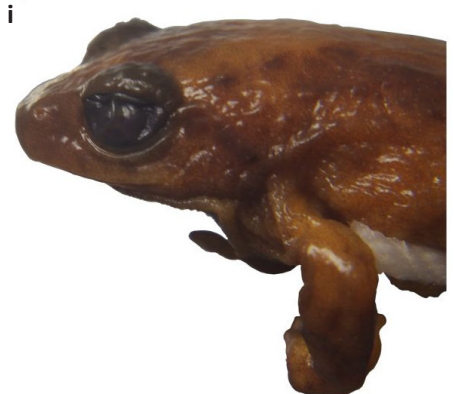

Image 2. Ventral (a-c), dorsal (d-f) and lateral ( $\mathrm{g}-\mathrm{i})$ view of head of Raorchestes ghatei sp. nov. holotype BNHS 5579 (a, d, $\mathrm{g}$ ), R. bombayensis typotye material 4589 (b, e, h) and R. tuberohumerus paratype BNHS 4194 (c, f, i).

papilla but with a lingual pit, (7) nuptial pad absent; (8) a bony tubercle on humerus at the end of deltoid ridge present in adult males but absent in females; (9) skin finely granulated or smooth above; (10) lateral side marbled with white blotches on brown background.

\section{DESCRIPTION}

Morphometric data are listed in Table 1. General body shape as in Image 1 . Dorsal, ventral and lateral view of head as in Image 2. Maximum size $25.5 \mathrm{~mm}$ SVL in male and $29.8 \mathrm{~mm}$ SVL in female.

Holotype (BNHS 5579, male) (all measurements in mm):

Medium sized frog (SVL 22.0), with robust body; head length (HL 7.8) shorter than head width (HW 8.6; MN 7.3; MFE 5.3; MBE 2.5); outline of snout in dorsal view mucronate (Image 2d); snout length (SL 3.1) shorter than horizontal diameter of eye (EL 3.2); canthus rostralis angular, loreal region obtuse, concave; ratio of distance between anterior margins of the eyes (IFE 5.1 ) to distance between posterior margins of eyes (IBE 6.0) 1:1.16; tympanum (TYD 1.1) indistinct, rounded, almost one-third of the eye diameter; supratympanic fold distinct, from posterior corner of upper eyelid to shoulder; tongue bifid, without papilla but with a lingual pit (Image 3); infratympanic fold distinct, from posterior margin of lower jaw joining to the supratympanic fold; interorbital distance (IUE 3.7) 2.4 times greater than width of upper eyelid (UEW 1.5).

Fore limbs: hand length (HAL 6.2) > humeral length (5.8) > forelimb (FLL 5.2); fingers with lateral (inner as well as outer) dermal fringes (Image 4a), webbing absent; subarticular tubercles prominent, rounded, single; single palmer tubercles present; supernumerary 


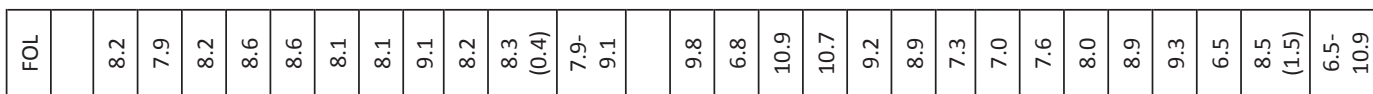

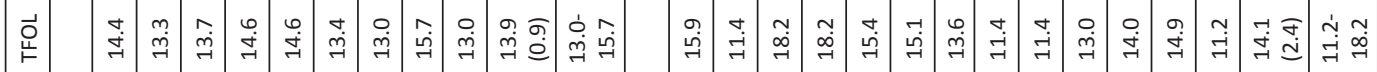

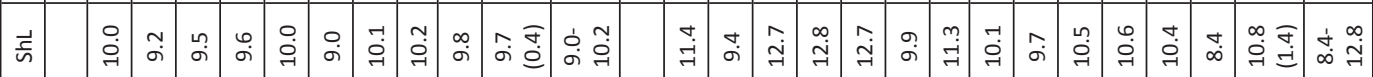

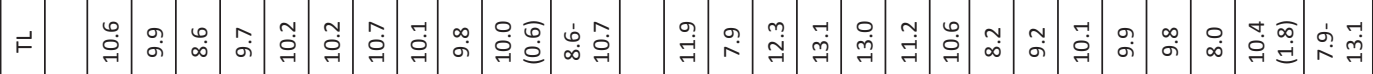

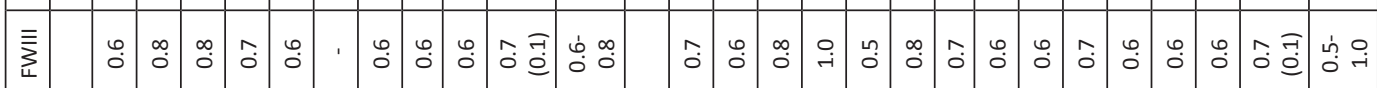

言

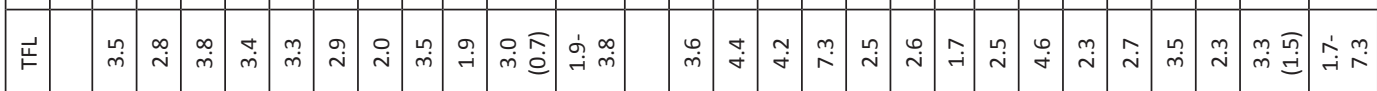

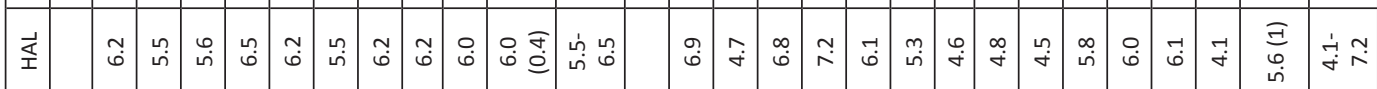

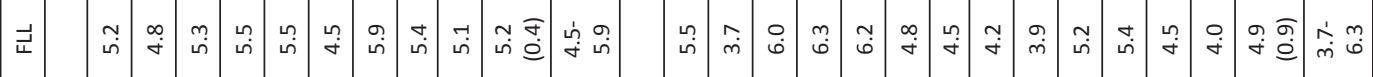

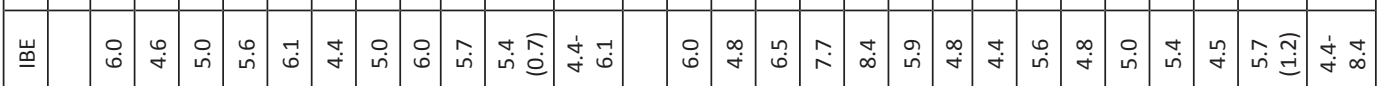

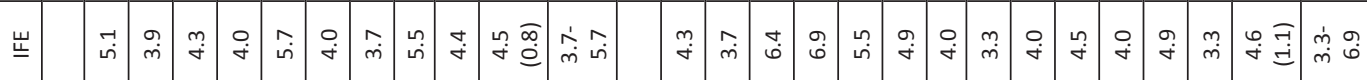

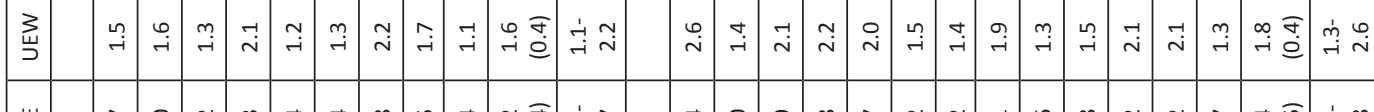

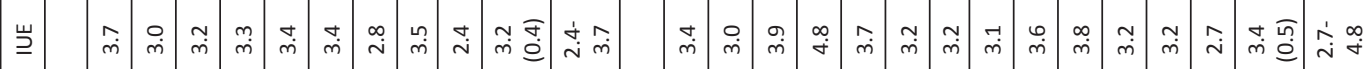

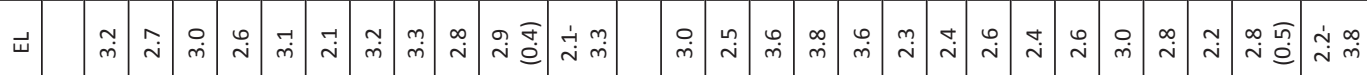

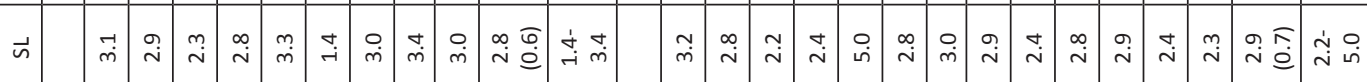

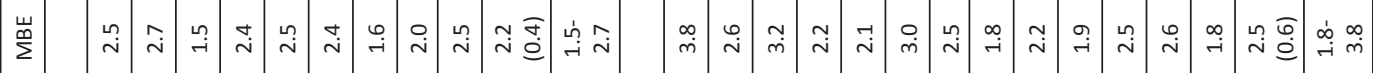

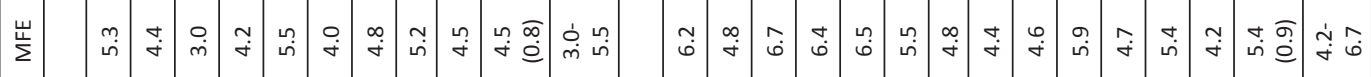

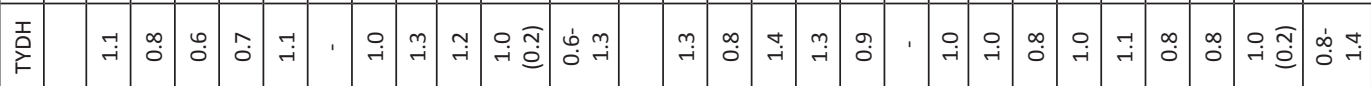

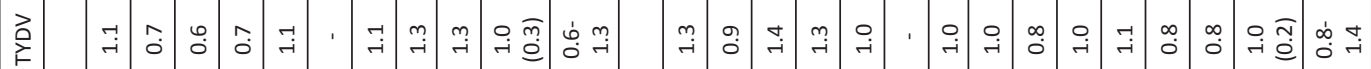

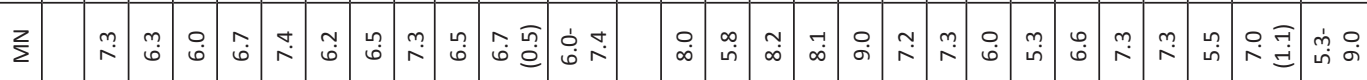

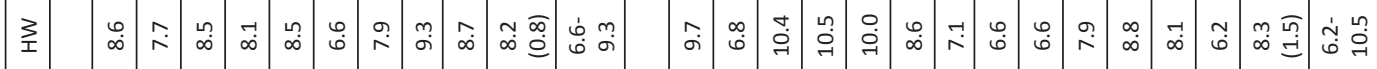

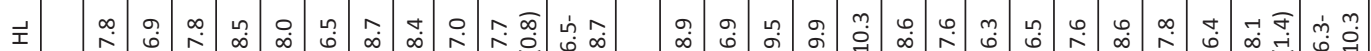

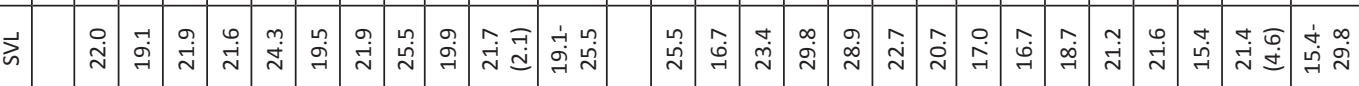

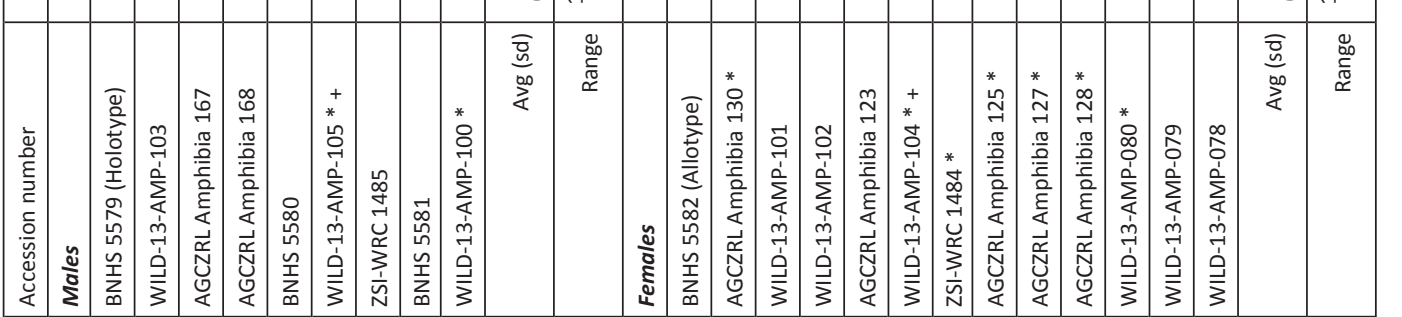



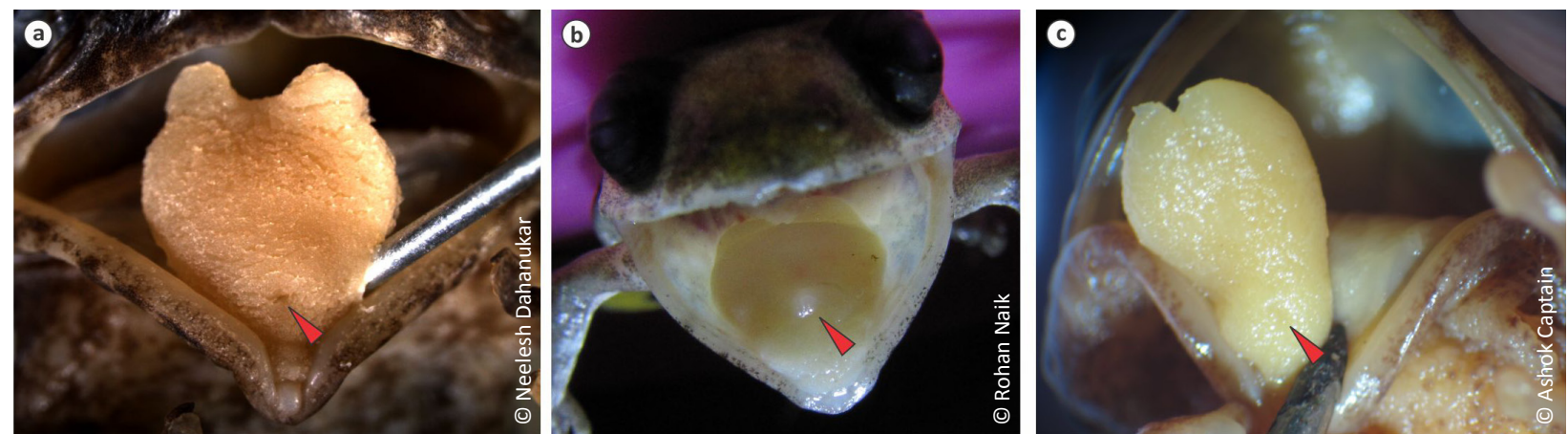

Image 3. Structure of tongue in Raorchestes ghatei sp. nov. (a), R. bombayensis (b) and $R$. tuberohumerus (c). In $R$. ghatei sp nov. and $R$. tuberohumerus tongue devoid of papilla but with a lingual pit (pointed with red arrow), while in $R$. bombayensis a well-defined papilla is present.

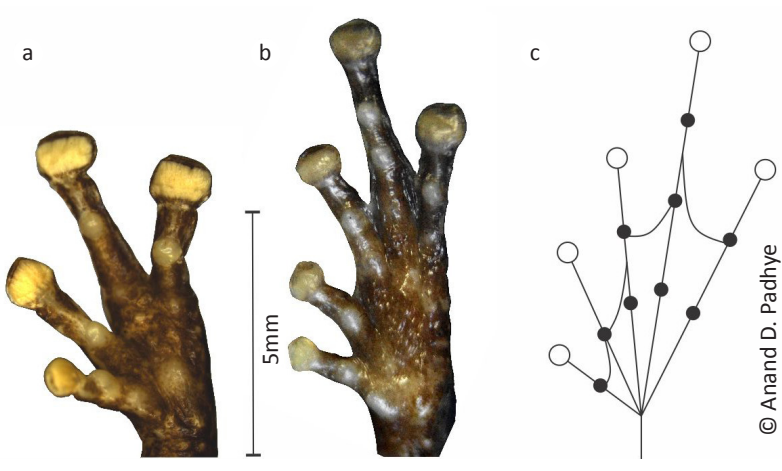

Image 4. Palm (a) and foot (b) of Raorchestes ghatei sp. nov.

Diagrametic representation of the webbing formula is depicted in (c).

tubercles indistinct, nuptial pad absent; finger length 3 (TFL 3.5) > finger length 2 (2.1) > finger length 4 (1.8) > finger length 1 (1.0); bony tubercle on humerus at the end of deltoid ridge as its extension in male (Image 5).

Hind limbs: moderately long, shank (ShL 10.0) shorter than thigh (TL 10.6), longer than the distance from the base of the inner metatarsal tubercle to the tip of the fourth toe that is foot (FOL 8.2); distance from the heel to tip of the fourth toe (TFOL 14.4) > thigh length (TL 10.6) > shank length (ShL 10.0) > distance from the base of the inner metatarsal tubercle to the tip of the fourth toe (FOL 8.2); webbing reduced (Image 4b); reaching up to penultimate subarticular tubercle on either side of IV toe; webbing formula (I2-2II2-2 $\frac{1}{2}|| \mid 2-3 I V 2 \frac{1}{2}-2 \mathrm{~V}$ ) (Image 4c); dermal fringe absent; subarticular tubercles single, round; tarsal fold and tarsal fringe absent; toe length $4(5.1)>$ toe length $3(3.1)=$ toe length $5(3.1)>$ toe length 2 (1.9) > toe length 1 (1.3); toe discs prominent with circum marginal groove; inner metatarsal tubercle simple, oval; outer metatarsal tubercle absent (Image $4 b)$; heels barely touch when legs are folded at right angles to body.

Snout with granular dorsal skin, inter-orbital space
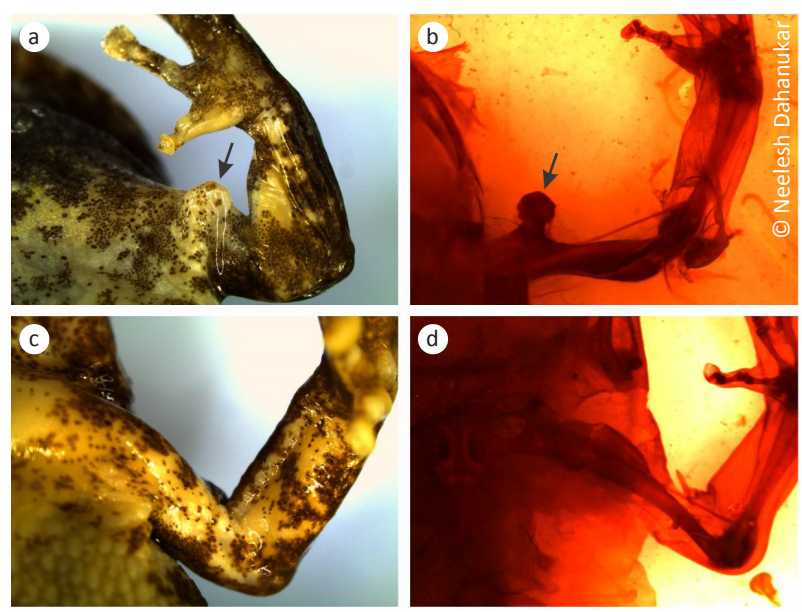

Image 5. Sexual dimorphic character in Raorchestes ghatei sp. nov. Tubercle is present on the humerus in male (a-b) but not in females (c-d). (a) holotype BNHS 5579, (b) WILD-13-AMP-102, (c) WILD-13AMP-105 and (d) WILD-13-AMP-104.

with smooth skin; skin on the back with minute sparsely located horny spinules; less in number as well as less conspicuous (Image $2 \mathrm{~d}$ ) as compared to R. bombayensis (Image 2e). Some variants show tubercles on the back.

Outer margins of dorso-lateral bands with inconspicuous dorso-lateral glandular folds, more evident in live specimens. Skin coarsely granular laterally. Gular skin rather smooth. Ventral skin in trunk region coarsely granular from chest to groin. Granulation extends up to thigh.

Colouration in life (Image 6): Dorsum greyish-brown with dark brown marbling. Black dorso-lateral band extending from tympanum converging in and then diverging to groin is present. Fore limbs dark without crossbars while thigh and shank with single cross bar. Creamish-yellow spots on dark background near the groin. Ventral skin in the trunk region is creamish in colour. A few dark spots present near fore limbs. 

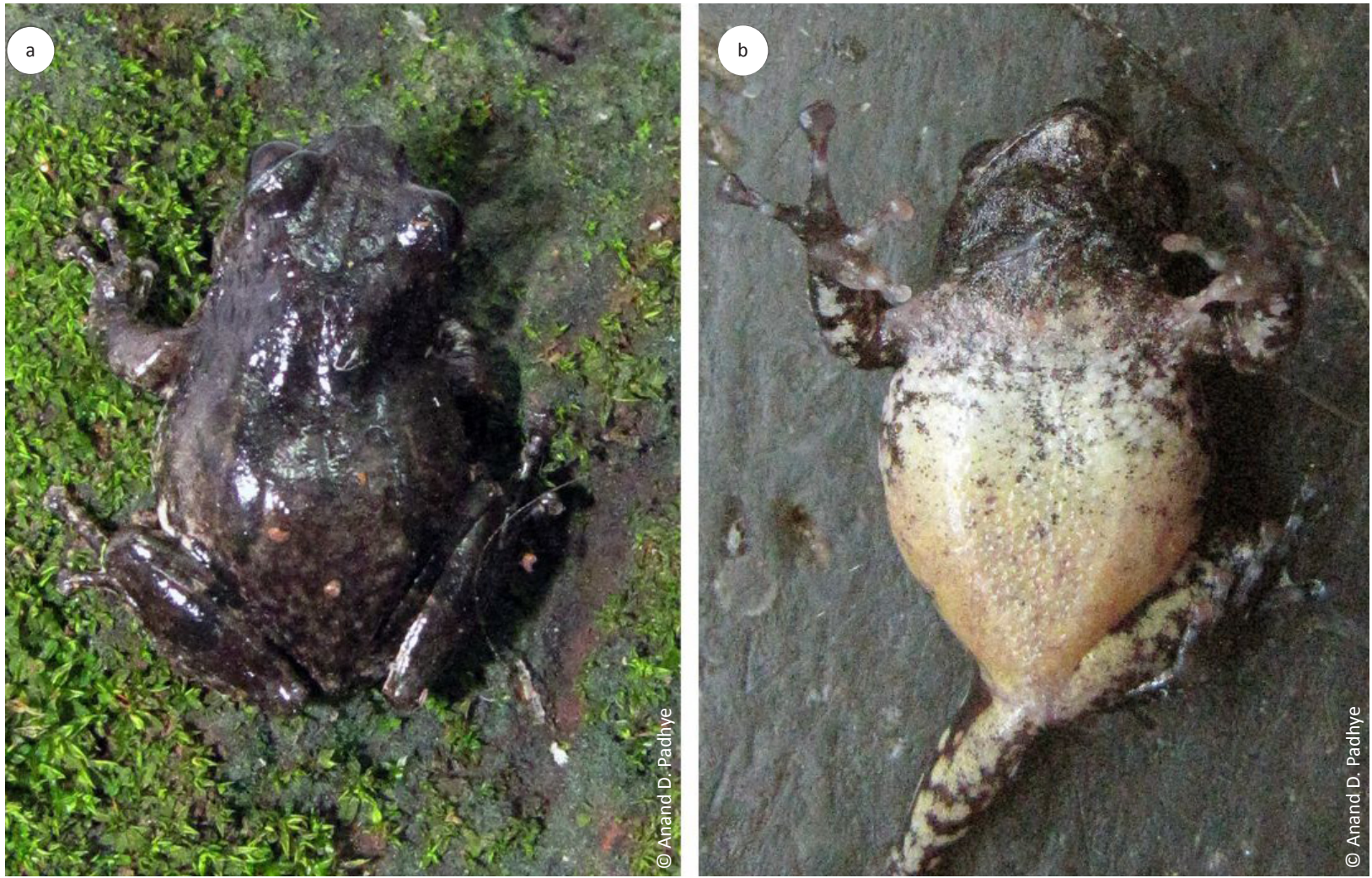

Image 6. Dorsal (a) and ventral (b) view of holotype of Raorchestes ghatei sp. nov. in life.

Yellowish-orange colour towards the posterior end of trunk. Gular skin marbled with dark spots, sometimes with reddish tinge.

In preservation (Image 1): Colour pattern in alcohol preserved specimens as in live conditions albeit faded

Allotype (BNHS 5582, female) (all measurements in $\mathrm{mm})$ :

Medium sized frog (SVL 25.5), with robust body; head length ( $\mathrm{HL}$ 8.9) shorter than head width (HW 9.7; MN 8.0; MFE 6.2; MBE 3.8); outline of snout in dorsal view mucronate; snout length (SL 3.2) slightly longer than horizontal diameter of eye (EL 3.0); canthus rostralis angular, loreal region obtuse, concave; ratio of distance between anterior margins of the eyes (IFE .4.3) to distance between posterior margins of eyes (IBE 6.0) 1:1.40; tympanum (TYD 1.3) indistinct, rounded, almost one-third of the eye diameter; supratympanic fold distinct, from posterior corner of upper eyelid to shoulder; tongue bifid, without papilla but with a lingual pit; infratympanic fold distinct, from posterior margin of lower jaw joining to the supratympanic fold; interorbital distance (IUE 3.4) 1.3 times greater than width of upper eyelid (UEW 2.6).
Fore limbs: hand length (HAL 6.9) > humeral length (6.6) > forelimb (FLL 5.5); fingers with lateral (inner as well as outer) dermal fringes, webbing absent; subarticular tubercles prominent, rounded, single; single palmer tubercles present; supernumerary tubercles indistinct; finger length 3 (TFL 3.6) > finger length 2 (2.5) > finger length 4 (2.2) > finger length 1 (1.9); bony tubercle on humerus at the end of deltoid ridge absent.

Hind limbs: moderately long, shank (ShL 11.4) shorter than thigh (TL 11.9), longer than the distance from the base of the inner metatarsal tubercle to the tip of the fourth toe that is foot (FOL 9.8); distance from the heel to tip of the fourth toe (TFOL 15.9) > thigh length (TL 11.9) > shank length (ShL 11.4) > distance from the base of the inner metatarsal tubercle to the tip of the fourth toe (FOL 9.8); webbing reduced; reaching up to penultimate subarticular tubercle on either side of IV toe; webbing formula (I2-2II2-21/2III2-3IV21/2-2V); dermal fringe absent; subarticular tubercles single, round; tarsal fold and tarsal fringe absent; toe length $4(5.0)>$ toe length $3(3.7)=$ toe length $5(3.7)>$ toe length $2(2.3)$ $>$ toe length 1 (1.8); toe discs prominent with circummarginal groove; inner metatarsal tubercle simple, oval; outer metatarsal tubercle absent (Image 4b); heels 

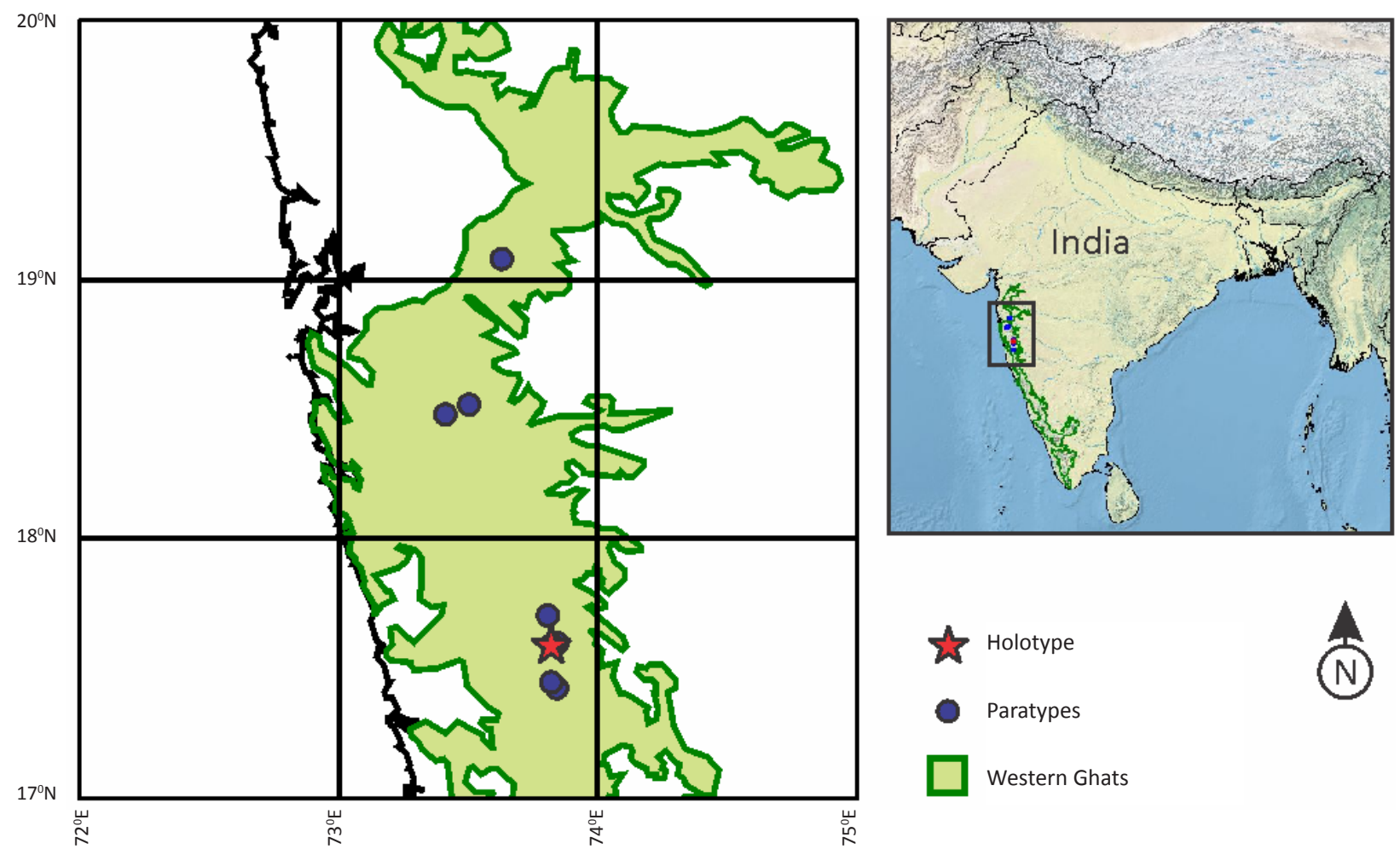

Figure 1. Distribution map of Raorchestes ghatei sp. nov.
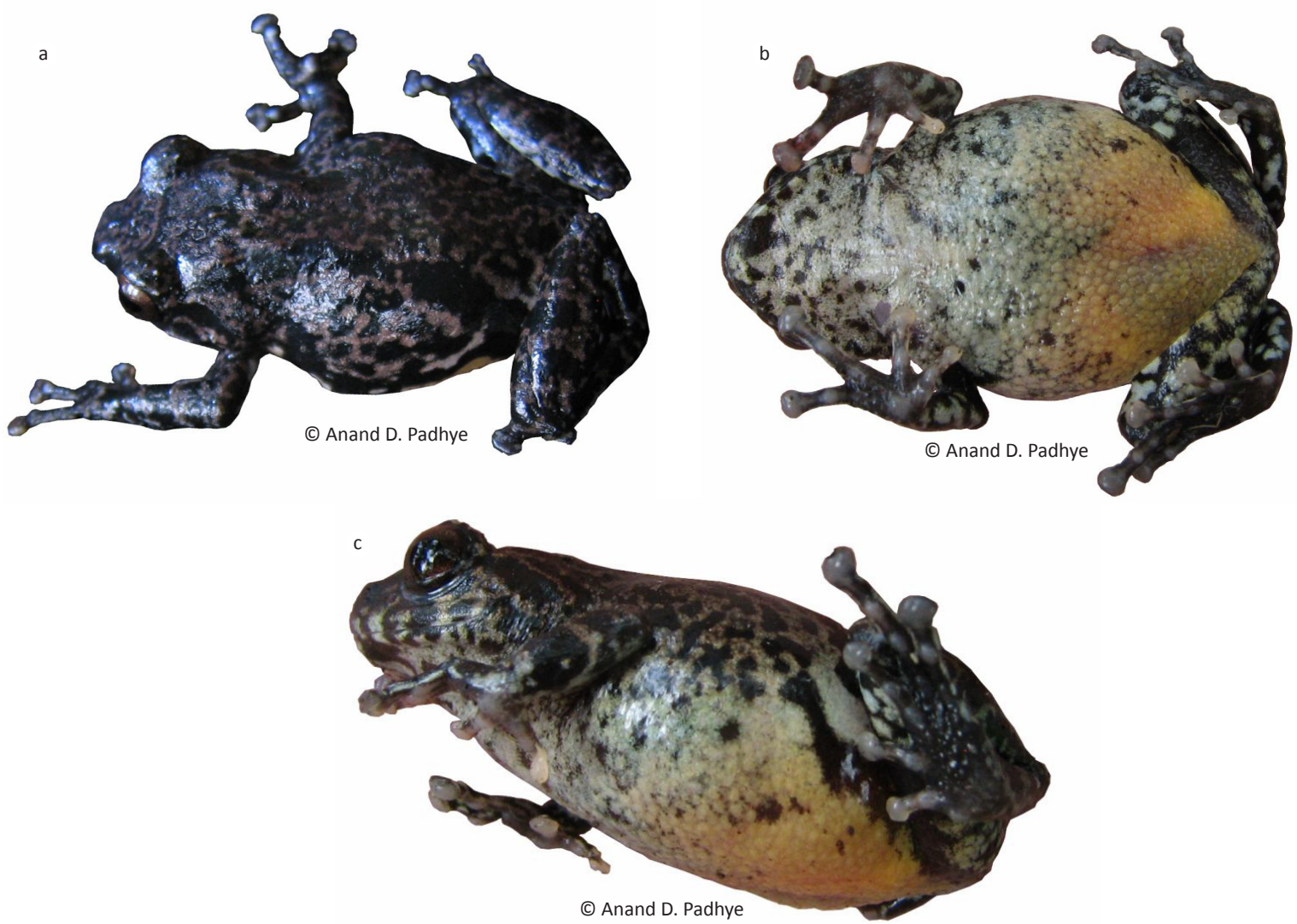

Image 7. Dorsal (a), ventral (b) and lateral (c) view of Raorchestes ghatei sp. nov. female (allotype BNHS 5582). 

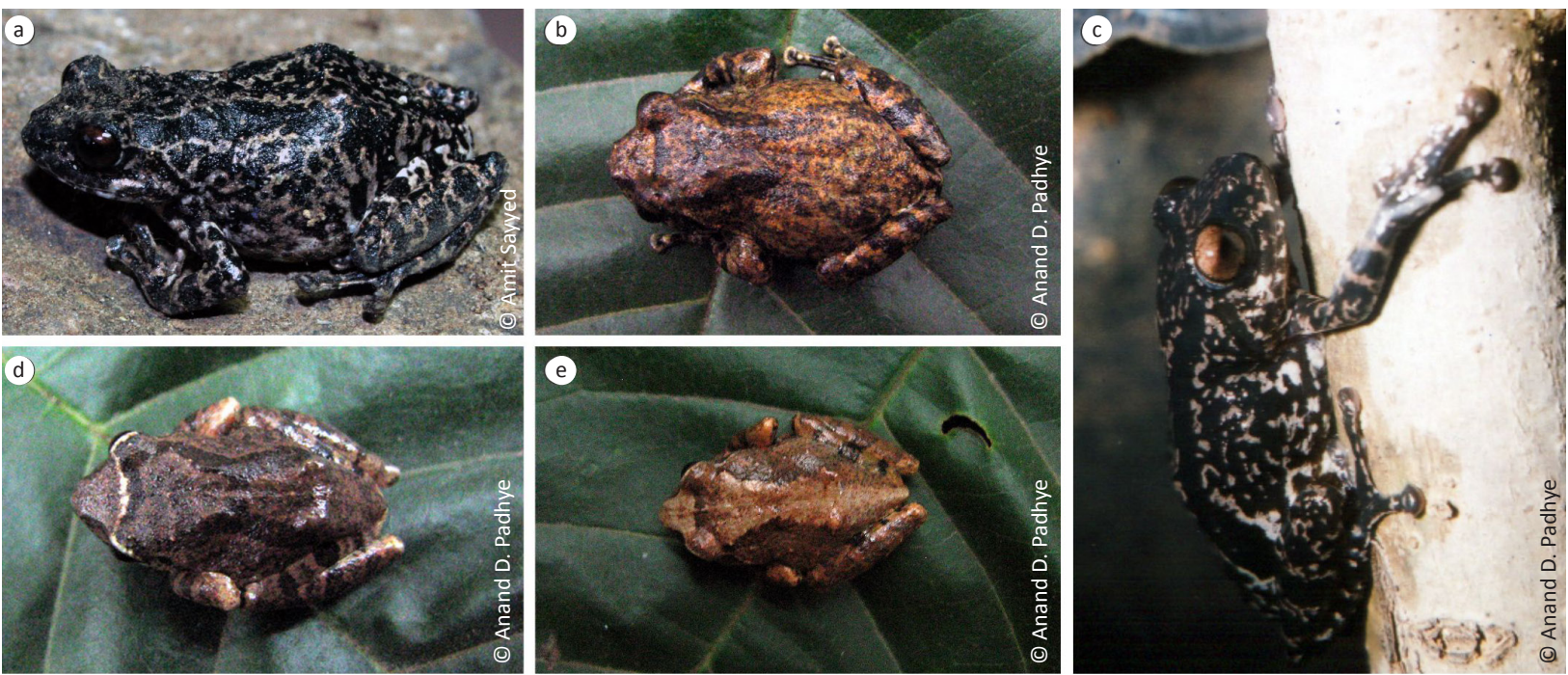

Image 8. Colour variation in live specimens of Raorchestes ghatei sp. nov. (a) specimen from Kaas, not collected, (b) WILD-13-AMP-100 (Paratype) from Thoseghar, (c) specimen from Thoseghar, not collected, (d) AGCZRL Amphibia 128 (Paratype) from Thoseghar and (e) female from Kaynanagar photographed in July 2002 (specimen not collected).

barely touch when legs are folded at right angles to body.

Colouration in life (Image 7): Dorsum blackish with creamish-white marbling. Black dorso-lateral bands extending from tympanum converging in and then diverging to groin are present. Fore limbs and hind limbs dark with crossbars. Creamish-yellow spots on dark background near the groin. Ventral skin in the trunk region is creamish in colour. A few dark spots present near fore limbs. Yellowish-orange colour towards the posterior end of trunk. Gular skin creamish in colour marbled with dark spots.

In preservation: Colour pattern in alcohol preserved specimen more or less similar as in live condition except for the creamish marbling on the back, which is lost in preservation.

\section{Colour variation}

Variation in colour pattern is shown in Image 8. Colour variation on the flanks and thigh region is shown in Image 9. A faint white stripe between anterior margins of upper eye lids (absent in holotype) may or may not be present.

\section{Sexual dimorphism}

Males of the species have a bony tubercle on the humerus at the end of deltoid ridge as its extension, which is absent in females (Image 5); males also posses single, sub-gular vocal sac, however, nuptial pads are absent.

\section{ETYMOLOGY}

The species is named after Dr. H.V. Ghate for his contributions to the herpetology of Western Ghats of Maharashtra.

Common name: Ghate's Shrub Frog.

\section{NATURAL HISTORY}

Distribution: The species is widely distributed in the Western Ghats of Maharashtra (Fig. 1) and is currently known from Jaichiwadi $\left(17.42^{\circ} \mathrm{N} \& 73.85^{\circ} \mathrm{E}, 1005 \mathrm{~m}\right)$ in the south and Taleghar near Bhimashankar $\left(19.08^{\circ} \mathrm{N} \&\right.$ $73.64^{\circ} \mathrm{E}, 1025 \mathrm{~m}$ ) in the north.

Habitat: Usually inhabit semi-evergreen forests and scrub patches (Image 10). Females usually found underneath loose stones while males are found calling on the branches of shrubs or even on trunks of trees, up to $5 \mathrm{~m}$ above ground.

Biology: The species has a direct development mode without free-swimming tadpoles. The eggs are laid in soil under loose stones on the forest floor (Image 11a). Development occurs within the egg (inside the vitelline membrane) (Image 11b) and fully metamorphosed juvenile emerges from the egg (Image 11c).

\section{GeNeTIC ANALYSIS}

Maximum likelihood analysis of 16S rRNA gene for all species of Raorchestes available on NCBI suggested that Raorchestes ghatei sp. nov. is genetically different from known species of Raorchestes and forms a monophyletic clade nested within the generic clade of Raorchestes with high bootstrap value (Fig. 2, Appendix B and C). 


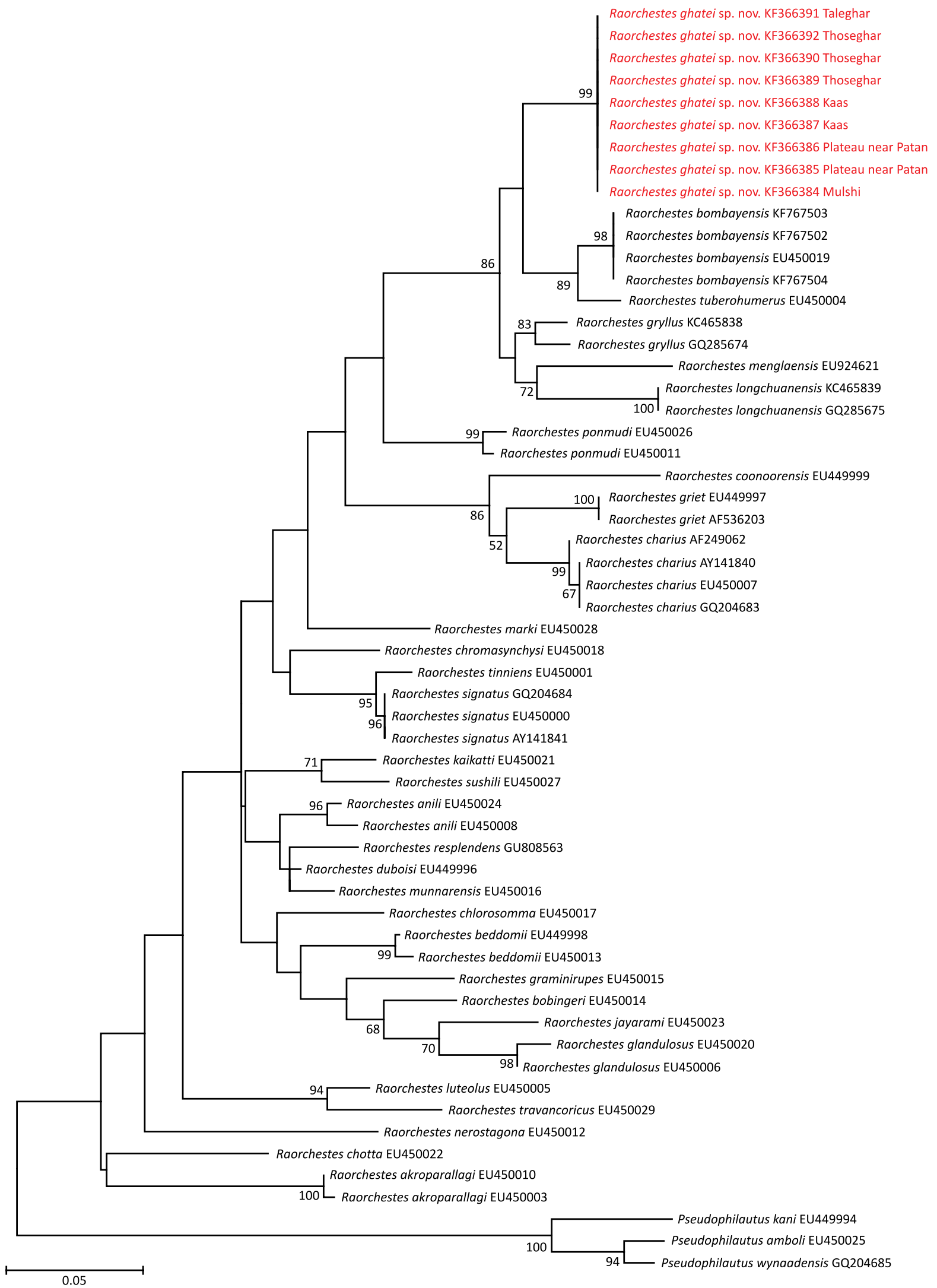

Figure 2. Maximum likelihood analysis of partial 16S rRNA gene. Tree for all Raorchestes species for which 16S rRNA gene data is available where the new species is depicted in red. Values on the node are percent bootstrap values for $\mathbf{1 0 0 0}$ iterations. Pseudophilautus species from Western Ghats are used as outgroup. 

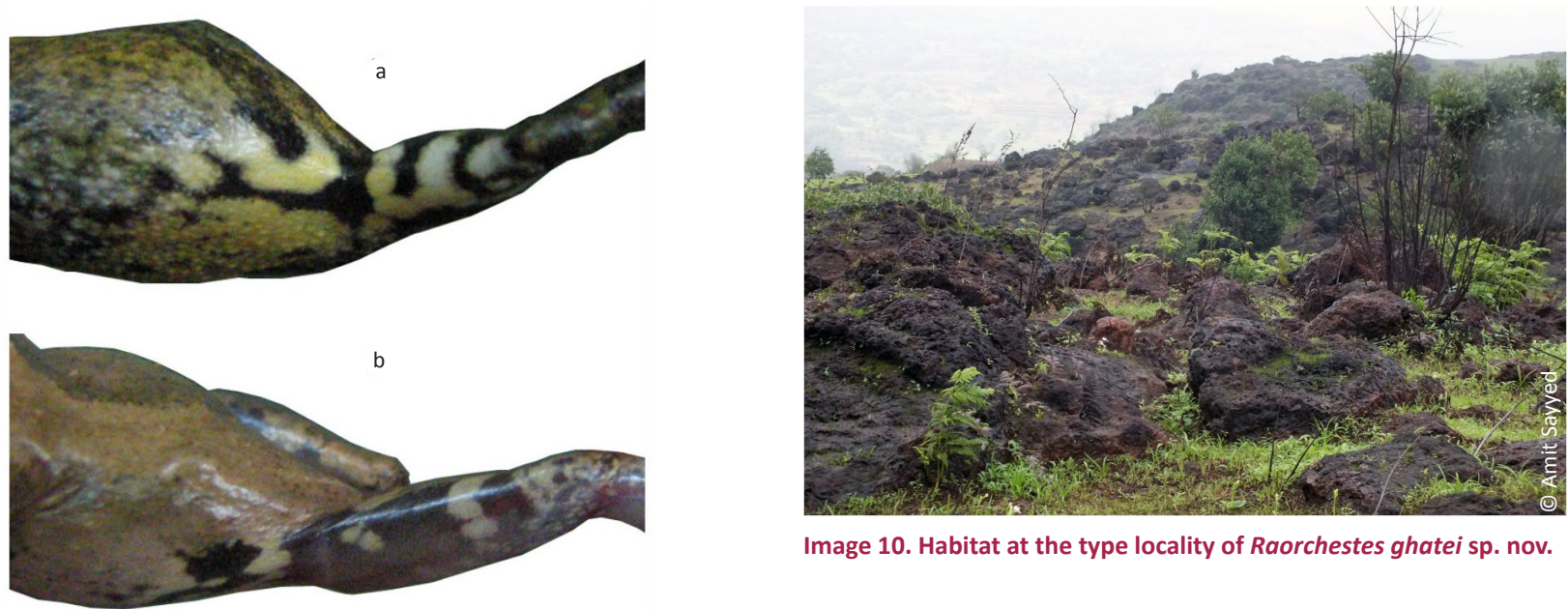

Image 10. Habitat at the type locality of Raorchestes ghatei sp. nov.
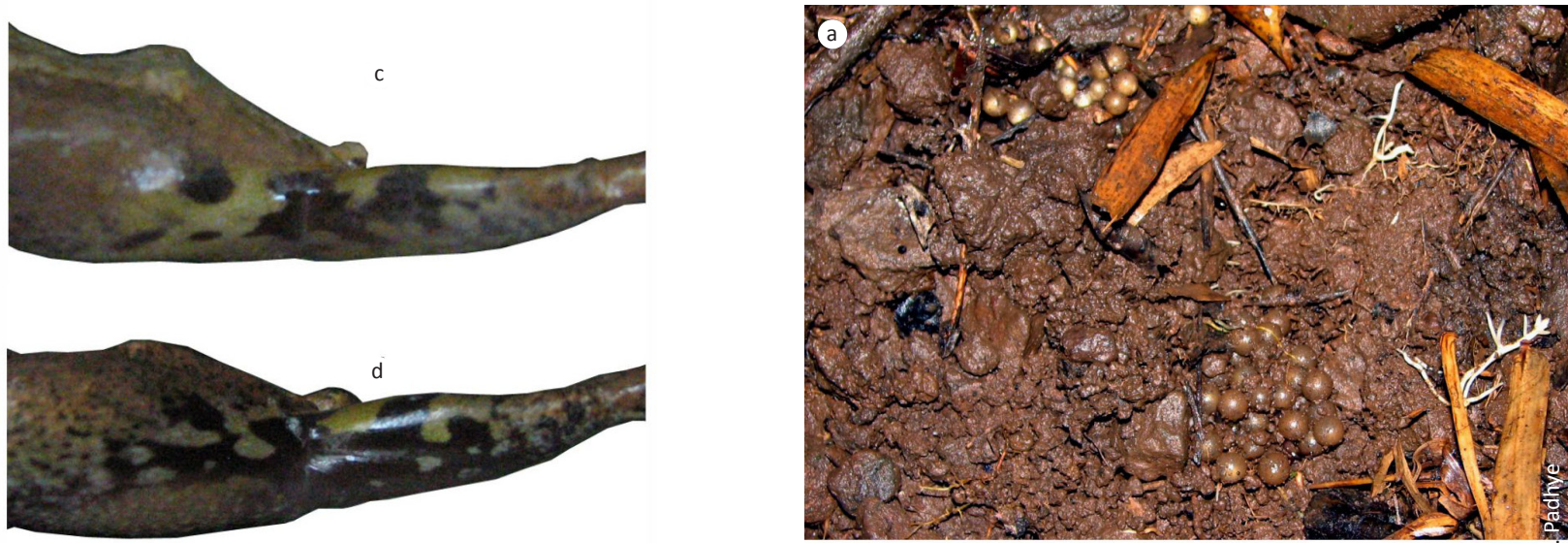
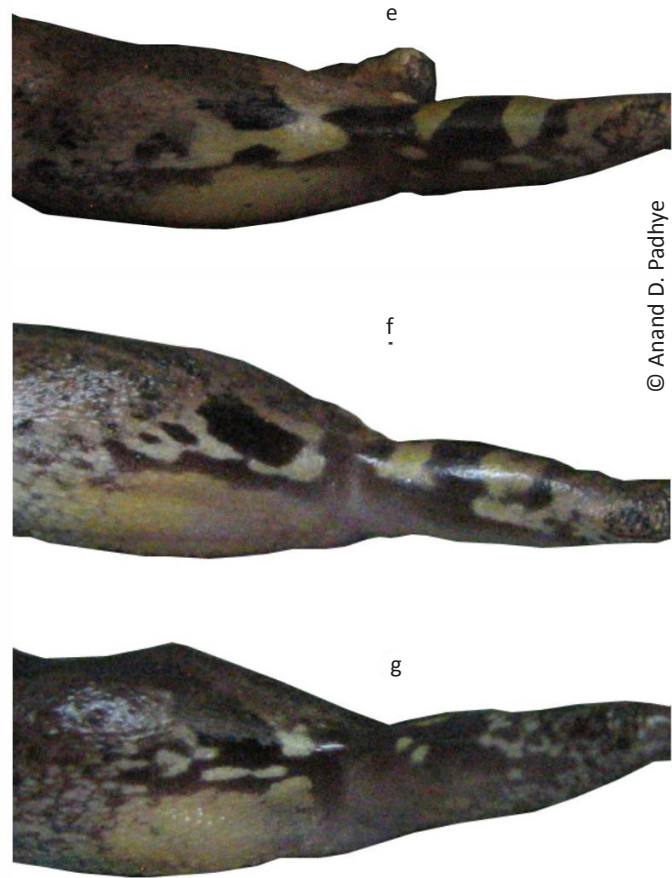

Image 9. Colour and pattern variation on the flank and thigh region of Raorchestes ghatei sp. nov. in life. All specimens are from the single population at Thoseghar. Specimens not collected.
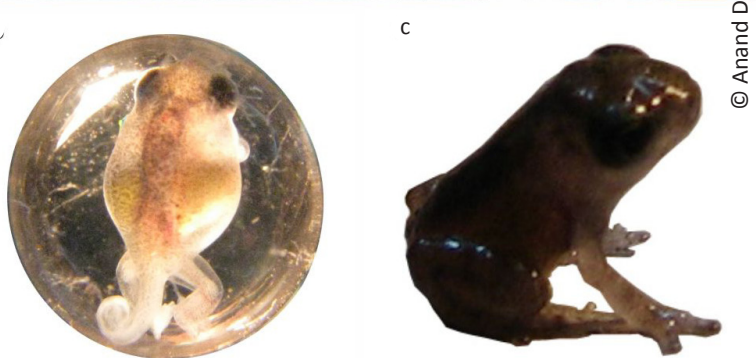

Image 11. Developmental stages of Raorchestes ghatei sp. nov. (a) Eggs clutches under the stone on forest floor in Dongarwadi, (b) developing embryo in the egg and (c) newly hatched juvenile.

Pair wise distance between $R$. ghatei sp. nov. and the two closest Western Ghats congener $R$. bombayensis and $R$. tuberohumerus was $4.9 \%$ and $4.5 \%$ respectively, while the distance between $R$. bombayensis and $R$. tuberohumerus was just $2.2 \%$. We could not include the following species in the analysis as the 16S rRNA data were not available: Raorchestes annandalii (Boulenger, 1906), R. flaviventris (Boulenger, 1882), R. kakachi Seshadri et al., 2012, R. manipurensis (Mathew \& Sen, 2009), R. parvulus (Boulenger, 1893), R. sahai (Sarkar \& Ray, 2006), R. shillongensis (Pillai \& Chanda, 1973), $R$. 


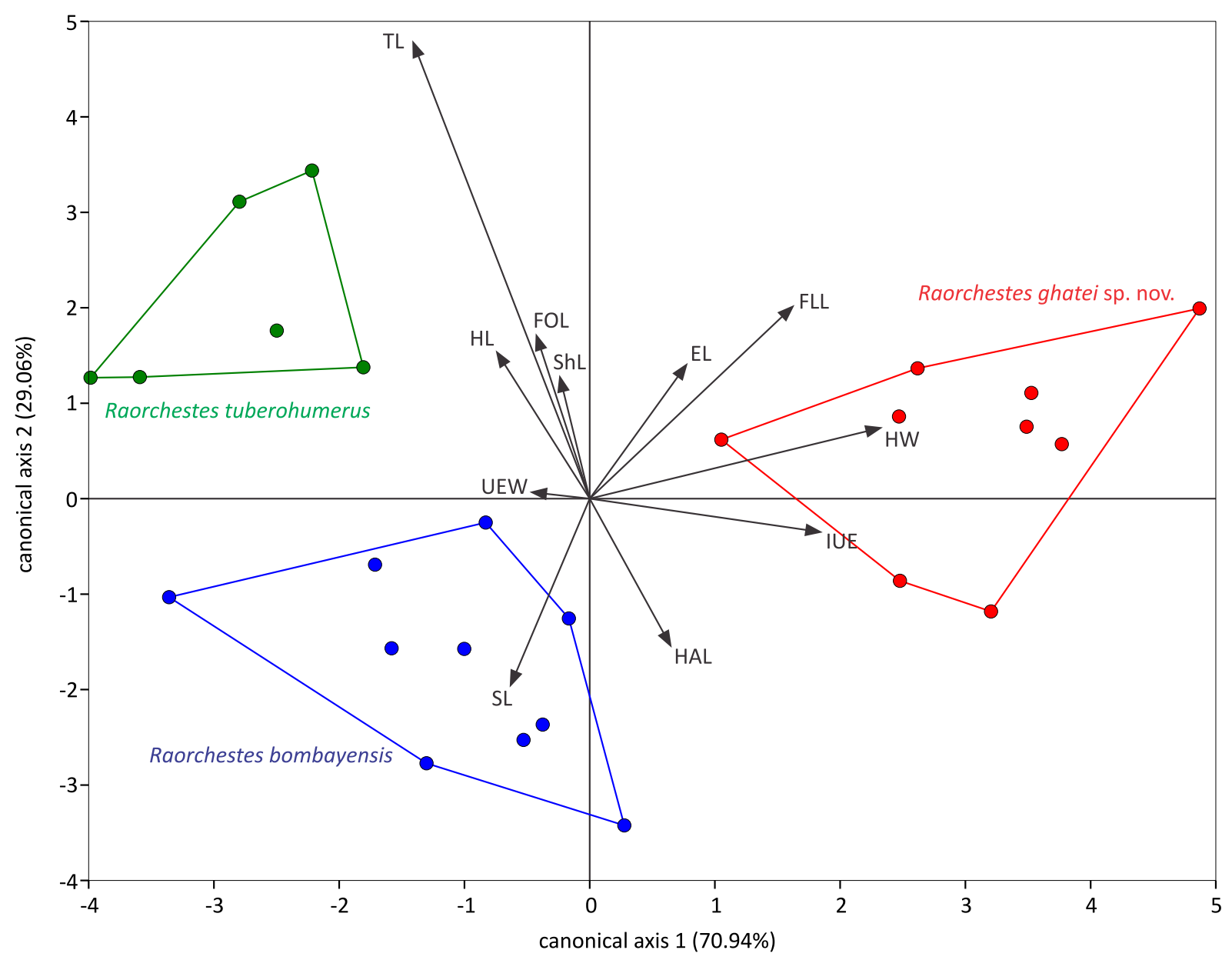

Figure 3. MANOVA/CVA of size adjusted morphometric data as percentage of SVL for adult males. Raorchestes ghatei sp. nov. forms a separate cluster distinct from $R$. bombayensis and $R$. tuberohumerus on the first canonical axis.

terebrans (Das \& Chanda, 1998) and R. thodai Zachariah et al., 2011. However, these species are morphologically distinct and have different geographical distributions. The following species were included in the earlier draft of the manuscript but are removed from the current analysis as the sequences which were then available in the public database were made unavailable while the manuscript was in review: Raorchestes uthamani Zachariah et al., 2011 (JX092722), R. agasthyaensis Zachariah et al., 2011 (JX092723, JX092646), $R$. chalazodes (Günther, 1876) (JX092676), R. crustai Zachariah et al., 2011 (JX092677), R. johnceei Zachariah et al., 2011 (JX092679), R. kadalarensis Zachariah et al., 2011 (JX092702, JX092701), R. manohari Zachariah et al., 2011 (JX092674), R. ochlandrae (Gururaja et al., 2007) (JX092666) and $R$. theuerkaufi Zachariah et al., 2011 (JX092693). Genetically, R. ghatei sp. nov. is different from these species.

\section{STATISTICAL ANALYSIS}

Size adjusted morphometric data was multivariate normal (Doornik \& Hansen omnibus, $E p=29.19, P=$ $0.1395)$. Three species formed significantly different clusters in MANOVA/CVA (Pillai's trace $=1.593, F_{22,26}$ $=4.624, P=0.0002$ ). Fisher's distances among the three clusters were significant ( $R$. ghatei sp. nov. vs. $R$. bombayensis, $F=7.099, P=0.001 ; R$. ghatei sp. nov. vs. $R$. tuberohumerus, $F=14.765, P<0.0001 ; R$. bombayensis vs. $R$. tuberohumerus, $F=3.929, P=0.014)$. Raorchestes ghatei sp. nov. differs from $R$. bombayensis and $R$. tuberohumerus in having longer inter-upper eyelid width (IUE), fore limb length (FLL) and head width (HW) (Fig. 3). Raorchestes ghatei sp. nov. differs from $R$. bombayensis in having lesser snout length (SL) to eye length (EL) ratio (Fig. 4). Raorchestes ghatei sp. nov. differs from $R$. tuberohumerus in having higher inter upper eyelid width (IUE) (Fig. 4a) and snout the vent length (SVL) (Fig. 4b). 

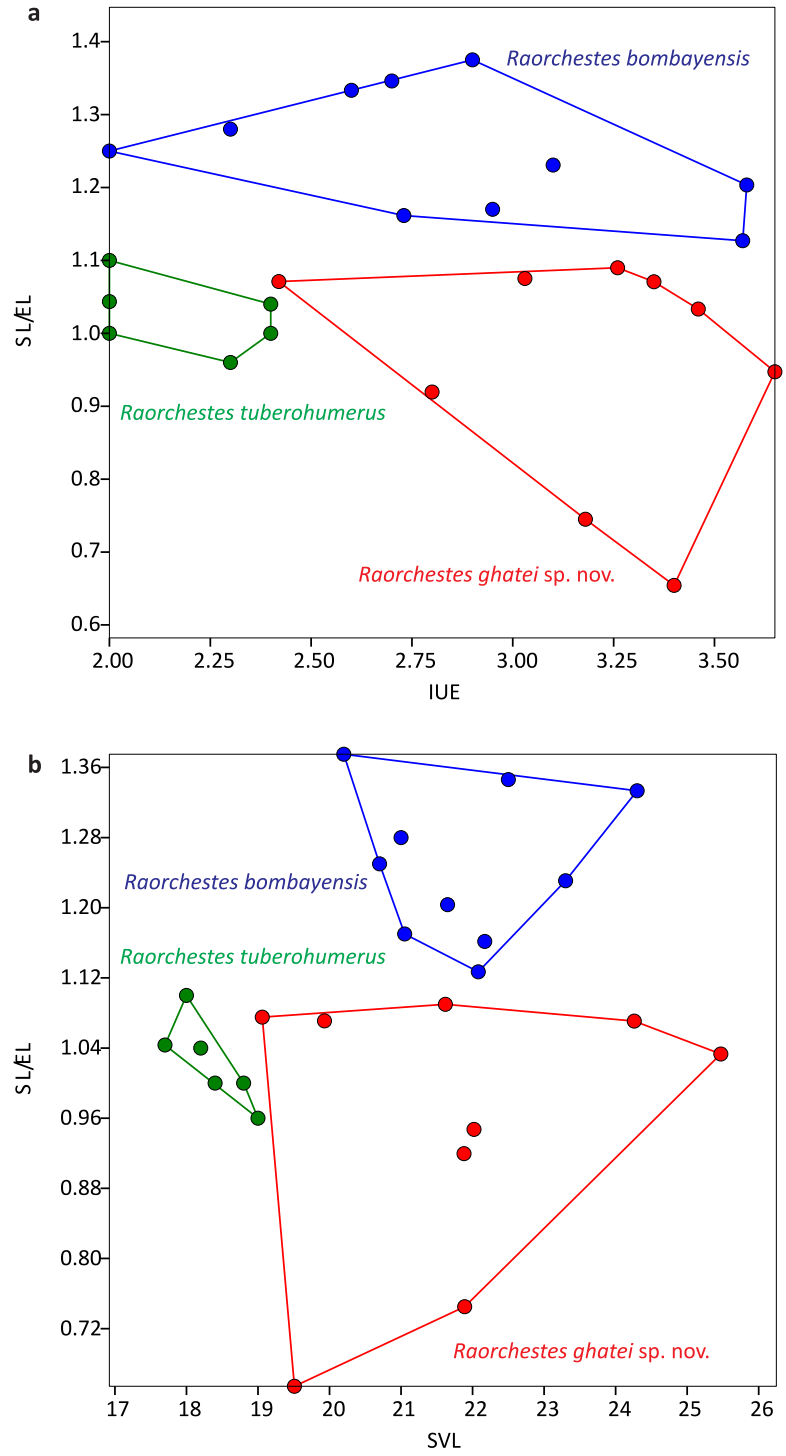

Figure 4. Morphometric differences between males of Raorchestes ghatei sp. nov., $R$. bombayensis and $R$. tuberohumerus. (a) ratio of snout length (SL) and eye length (EL) vs. inter upper eyelid distance (IUE) and (b) ratio of SL and EL vs. snout vent length (SVL).

\section{DISCUSSION}

Annandale (1919) described Ixalus bombayensis (= Raorchestes bombayensis) from Castle Rock, and also mentioned that the species is more common in Khas (= Kaas) in Satara and Khandalla (= Khandala) in Poona (= Pune). However, Biju \& Bossuyt (2009) have restricted the northern most distribution of $R$. bombayensis to Amboli in Maharashtra. Biju \& Bossuyt (2009) in their revision of the taxa mentions that "Annandale's report of this species from 'Khas, Satara district' (ZSIC 18782-18813) and 'Khandalla, Poona district' (ZSIC 1814-1818), which are severely damaged specimens still

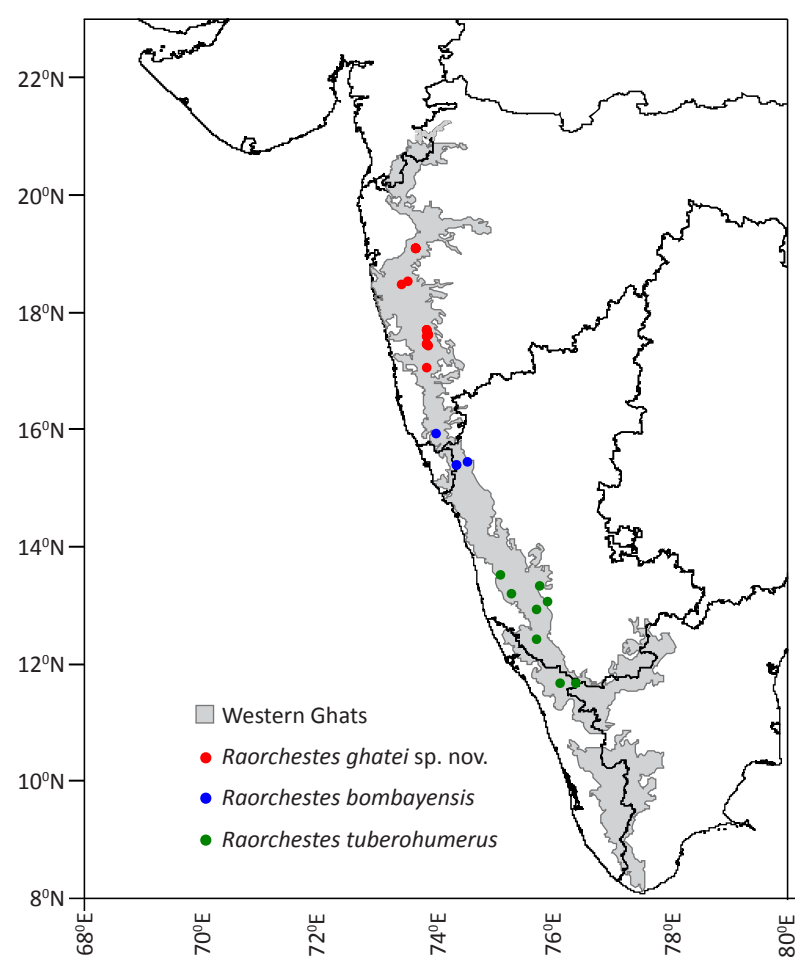

Figure 5. Distribution of three species based on current study and data provided in Biju \& Bossuyt (2009).

available at ZSIC (Annandale 1919), was in error". Our genetic and morphometric analysis of populations of Raorchestes found in Kaas and north up to Taleghar near Bhimashankar suggests that the taxa found in this area is indeed different from $R$. bombayensis, which is described as $R$. ghatei sp. nov. in the current communication. Distribution map for $R$. bombayensis, $R$. ghatei sp. nov. and $R$. tuberohumerus, based on the current knowledge of the distribution of the three species, as evident from Biju \& Bossuyt (2009) and the current study, is shown in Fig. 5. It is essential to note that the previous records of $R$. bombayensis from the northern Western Ghats, based on morphological characters, especially from the distribution range of $R$. ghatei sp. nov. need verification. Based on the examination of vouchers, we suggest that the records of $R$. bombayensis from Tamhini (Dahanukar \& Padhye 2005) and Taleghar (Dahanukar et al. 2013), should be considered as $R$. ghatei sp. nov. tuberohumerus from Thoseghar by Padhye \& Ghate (2012) should also be asigned to $R$. ghatei sp. nov.

Phylogenetically, Raorchestes ghatei sp. nov. is nested within a monophyletic group consisting of $R$. bombayensis and $R$. tuberohumerus from the Western Ghats and R. gryllus, R. longchuanensis and R. menglaensis from Viet Nam and China. Yu et al. $(2009,2010)$ have already suggested that some species of Raorchestes 
from China and Viet Nam are nested within the Western Ghats radiation of Raorchestes. Raorchestes ghatei sp. nov. has a distribution in between the southern most member $R$. tuberohumerus in this clade and the species in China and Viet Nam. Biogeographical significance of this finding, however, needs further investigations.

Raorchestes ghatei sp. nov. can be differentiated from the closely related species from the phylogenetic tree as follows. Raorchestes ghatei sp. nov. differs from $R$. bombayensis in absence of tongue papilla (vs. presence), absence of nuptial pad (vs. presence), dorsal skin finely granulated (vs. coarsely granulated) and lower SL/EL ratio (vs. higher). Raorchestes ghatei sp. nov. can be differentiated from $R$. tuberohumerus in having robust body (vs. slender body), longer SVL (vs. smaller), ventrally snout slightly projecting beyond mouth (vs. projecting beyond mouth), wider IUE (vs. narrow). Raorchestes ghatei sp. nov. differs from $R$. gryllus in having round pupil (vs. horizontal), small and indistinct tympanum (vs. big and distinct) relative to eye diameter, ventral surface coarsely granular (vs. slightly granular) and absence of dermal fringe (vs. well developed dermal fringe). Raorchestes ghatei sp. nov. differs from $R$. longchuanensis in ventrally snout slightly projecting beyond mouth (vs. projecting beyond mouth) and head wider than long (vs. longer or equal to wide). Raorchestes ghatei sp. nov. differs from $R$. menglaensis in having dorsal skin smooth or finely granulated (vs. coarsely granulated) and snout mucronate (vs. acutely pointed)

Osteological and genetic study of Raorchestes ghatei sp. nov. has revealed that the tubercle on the humeral bone, a character which was previously considered specific for $R$. tuberohumerus, is in fact a sexually dimorphic character present only in males. In the description of $R$. tuberohumerus, Kuramoto \& Joshy (2003) mentioned that they failed to collect females of the species. However, we believe that even in $R$. tuberohumerus, the females may be devoid of the tubercle on the humeral bone. Ecological significance of this sexually dimorphic character is yet to be determined but our initial observations suggests that it might be used by males for clasping the females during amplexus. Another possibility is that the tubercle might be useful in clinging to the small shrubs in windy habitats in Western Ghats. This is especially true for males who are found on the trunks giving the advertisement calls, while the females are mostly found on the ground.

Presence of a lingual pit in the case of Raorchestes ghatei sp. nov. (Image 3a), apposed to a papilla in the case of $R$. bombayensis is an interesting finding of our study. In an extensive review on median lingual processes in frogs, Grant et al. (1997) have suggested that the presence of a median lingual pit does not necessarily mean the presence of a median lingual process. While taking an example from the museum collection of American Museum of Natural History (AMNH), Grant et al. (1997) argued that in $R$. bombayensis there is presence of a pit rather than a retracted process. However, the specimen (AMNH 40044) photographed by Grant et al. (1997) is from Satara, which is within the distributional range of $R$. ghatei sp. nov. Therefore, the arguments raised by Grant et al. (1997) are for $R$. ghatei sp. nov. and not for $R$. bombayensis. Raorchestes bombayensis has a welldefined papilla which can be seen in live specimens (Image $3 b$ ) as well as the holotype of $R$. bombayensis (Appendix D). In R. tuberohumerus an ill-defined pit is present even though a papilla is absent (Image $3 c$ ).

Raorchestes ghatei sp. nov. is widely distributed in the Western Ghats of Maharashtra and is common in most of the forest patches. Even though no specific threats could be identified for the species, continuous deforestation in these areas leading to habitat fragmentation could be a threat to the species. Several localities from which the species is currently known are also subject to tourism and recreational activities. There is a large wind farm near the type locality at Chalkewadi and the other localities are also potential wind farm sites. Pande et al (2013) have discussed threat of wind farms to avifauna wherein they discuss the windmill erection activity to be a measured threat to general diversity as well. Recently, Dahanukar et al. (2013) reported the presence of chytrid fungal infection in morphologically identified $R$. bombayensis from Taleghar, which should be attributed to the $R$. ghatei sp. nov. based on the current study. Therefore, it can be suggested that the species is prone to chytrid infection. Even though the effect of chytrid on this species is not available, further studies are essential on this topic. Furthermore, a detailed study on the ecology, distribution, population status and threats to the populations is essential to evaluate the conservation status of this species.

\section{REFERENCES}

Abraham, R.K., R.A. Pyron, BR Ansil, A. Zachariah \& A. Zachariah (2013). Two novel genera and one new species of treefrog (Anura: Rhacophoridae) highlight cryptic diversity in the Western Ghats of India. Zootaxa 3640: 177-189; http://dx.doi.org/10.11646/ zootaxa.3640.2.3

Altschul, S.F., W. Gish, W. Miller, E.W. Myers \& D.J. Lipman (1990). Basic local alignment search tool. Journal of Molecular Biology 215: 403-410; http://dx.doi.org/10.1016/S0022-2836(05)80360-2 
Appendix A. Voucher and GenBank accession numbers for sequences used in molecular analysis.

\begin{tabular}{|c|c|c|c|c|c|}
\hline Species & Voucher & $\begin{array}{l}\text { GenBank } \\
\text { Accession } \\
\text { number }\end{array}$ & Species & Voucher & $\begin{array}{l}\text { GenBank } \\
\text { Accession } \\
\text { number }\end{array}$ \\
\hline Raorchestes ghatei sp. nov. & ZSI-WRC A/1484 & KF366384 & Raorchestes glandulosus & 1369PhiGla* & EU450020 \\
\hline Raorchestes ghatei sp. nov. & WILD-13-AMP-100 & KF366385 & Raorchestes glandulosus & 0077PhiGla* & EU450006 \\
\hline Raorchestes ghatei sp. nov. & AGCZRL-Amphibia-130 & KF366386 & Raorchestes graminirupes & BNHS 4266 & EU450015 \\
\hline Raorchestes ghatei sp. nov. & WILD-13-AMP-104 & KF366387 & Raorchestes griet & BNHS 4455 & EU449997 \\
\hline Raorchestes ghatei sp. nov. & WILD-13-AMP-105 & KF366388 & Raorchestes griet & - & AF536203 \\
\hline Raorchestes ghatei sp. nov. & AGCZRL-Amphibia-125 & KF366389 & Raorchestes gryllus & ROM 38828 & KC465838 \\
\hline Raorchestes ghatei sp. nov. & AGCZRL-Amphibia-127 & KF366390 & Raorchestes gryllus & ROM 30288 & GQ285674 \\
\hline Raorchestes ghatei sp. nov. & AGCZRL-Amphibia-128 & KF366391 & Raorchestes jayarami & SDB 1379 & EU450023 \\
\hline Raorchestes ghatei sp. nov. & WILD-13-AMP-080 & KF366392 & Raorchestes kaikatti & BNHS 4557 & EU450021 \\
\hline Raorchestes akroparallagi & 0317Phi018b* & EU450010 & Raorchestes longchuanensis & 7Rao & KC465839 \\
\hline Raorchestes akroparallagi & 0071Phi018* & EU450003 & Raorchestes longchuanensis & 5 Rao & GQ285675 \\
\hline Philautus anili & 1400PhiAni* & EU450024 & Raorchestes luteolus & BNHS 4478 & EU450005 \\
\hline Philautus anili & 0307PhiAni* & EU450008 & Raorchestes marki & BNHS 4537 & EU450028 \\
\hline Philautus beddomii & 0030PhiBed* & EU449998 & Raorchestes menglaensis & KIZ060821286 & EU924621 \\
\hline Philautus beddomii & 1153PhiBed* & EU450013 & Raorchestes munnarensis & BNHS 4481 & EU450016 \\
\hline Raorchestes bobingeri & BNHS 4273 & EU450014 & Raorchestes nerostagona & BNHS 4244 & EU450012 \\
\hline Raorchestes bombayensis & BNHS 4418 & EU450019 & Raorchestes ponmudi & 1451PhiPonb* & EU450026 \\
\hline Raorchestes bombayensis & WILD-13-AMP-230 & KF767502 & Raorchestes ponmudi & 1121PhiPon* & EU450011 \\
\hline Raorchestes bombayensis & WILD-13-AMP-231 & KF767503 & Raorchestes resplendens & SDB-2010 & GU808563 \\
\hline Raorchestes bombayensis & AGCZRL-Amphibia-172 & KF767504 & Raorchestes signatus & - & GQ204684 \\
\hline Raorchestes charius & - & AF249062 & Raorchestes signatus & BNHS 4489 & EU450000 \\
\hline Raorchestes charius & - & AY141840 & Raorchestes signatus & - & AY141841 \\
\hline Raorchestes charius & 0081PhiCha_type* & EU450007 & Raorchestes sushili & BNHS 4544 & EU450027 \\
\hline Raorchestes charius & - & GQ204683 & Raorchestes tinniens & BNHS 4548 & EU450001 \\
\hline Raorchestes chlorosomma & BNHS 4426 & EU450017 & Raorchestes travancoricus & BNHS 4557 & EU450029 \\
\hline Raorchestes chotta & BNHS 4429 & EU450022 & Raorchestes tuberohumerus & BNHS 4590 & EU450004 \\
\hline Raorchestes chromasynchysi & BNHS 4433 & EU450018 & Pseudophilautus kani & BNHS 4472 & EU449994 \\
\hline Raorchestes coonoorensis & BNHS 4446 & EU449999 & \multirow{2}{*}{$\begin{array}{l}\text { Pseudophilautus } \\
\text { wynaadensis }\end{array}$} & - & GQ204685 \\
\hline Raorchestes dubois & BNHS 5285 & EU449996 & & & \\
\hline
\end{tabular}

* Voucher numbers for these isolates cannot be determined based on the information given in Biju \& Bossuyt (2009).

Annandale N. (1919). The fauna of certain small streams in the Bombay presidency. Records of Indian Museum 16: 109-161.

Biju, S.D. \& F. Bossuyt (2009). Systematics and phylogeny of Philautus Gistel, 1848 (Anura, Rhacophoridae) in the Western Ghats of India, with descriptions of 12 new species. Zoological Journal of the Linnean Society 155: 374-444; http://dx.doi.org/10.1111/j.10963642.2008.00466.x

Biju, S.D., Y. Shouche, A. Dubois, S.K. Dutta \& F. Bossuyt (2010). A ground-dwelling rhacophorid frog from the highest mountain peak of the Western Ghats of India. Current Science 98: 1119-1125.

Biju, S.D., I.V. Bocxlaer, S. Mahony, K.P. Dinesh, C. Radhakrishnan, A. Zachariah, V. Giri \& F. Bossuyt (2011). A taxonomic review of the Night Frog genus Nyctibatrachus Boulenger, 1882 in the Western Ghats, India (Anura: Nyctibatrachidae) with description of twelve new species. Zootaxa 3029: 1-96.

Bini, L.M., J.A.F. Diniz-Filho, T.F. Rangel, R.P. Bastos \& M.P. Pinto (2006). Challenging Wallacean and Linnean shortfalls: knowledge gradients and conservation planning in a biodiversity hotspot. Diversity and Distributions 12: 475-482; http://dx.doi.org/10.1111/ j.1366-9516.2006.00286.x

Dahanukar, N. \& A. Padhye (2005). Amphibian diversity and distribution in Tamhini, northern Western Ghats, India. Current Science 88(9): 1496-1501.

Dahanukar, N., K. Krutha, M.S. Paingankar, A.D. Padhye, N. Modak \& S. Molur (2013). Endemic Asian chytrid strain Infection in threatened and endemic anurans of the northern Western Ghats, India. PLOS ONE 8(10): e77528; http://dx.doi.org//10.1371/journal. pone.0077528

Dinesh, K.P. \& C. Radhakrishnan (2011). Checklist of amphibians of Western Ghats. Frog Leg 16: 15-21.

Doornik, J.A. \& H. Hansen (2008). An Omnibus Test for Univariate and Multivariate Normality. Oxford Bulletin of Economics and Statistics 70: 927-939; http://dx.doi.org/10.1111/j.1468-0084.2008.00537.x Edgar, R.C. (2004). MUSCLE: multiple sequence alignment with high 


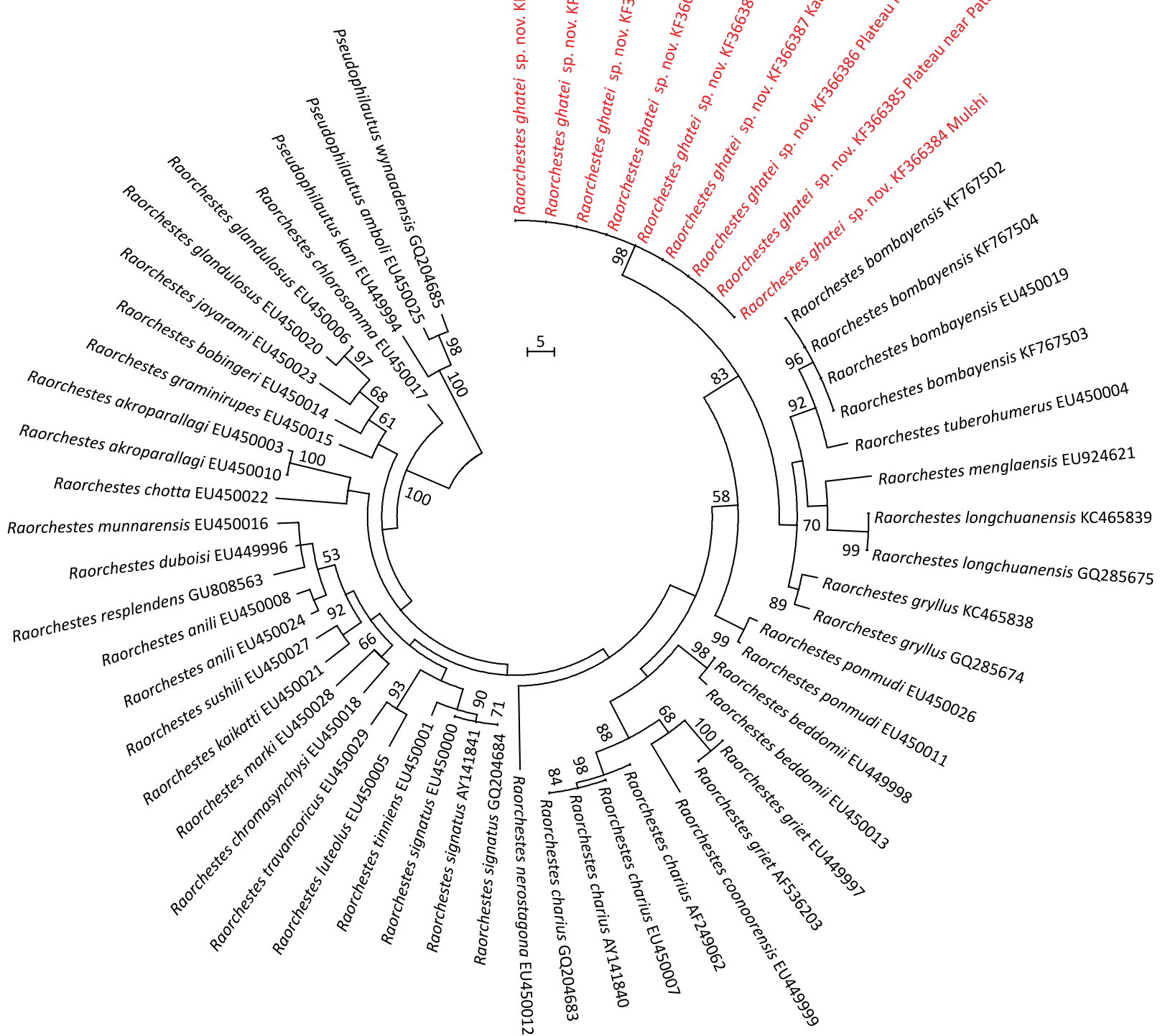

Appendix B. Maximum Parsimony based phylogenetic tree using 16S rRNA gene sequences of Raorchestes species. Pseudophilautus species from Western Ghats are used as outgroup. Values on the node are percent bootstrap values for 1000 iterations.

accuracy and high throughput. Nucleic Acids Research 32(5): 17921797; http://dx.doi.org/10.1093/nar/gkh340

Frost, D.R. (2013). Amphibian Species of the World: an Online Reference. Version 5.6 (9 January 2013). American Museum of Natural History, New York, USA. Electronic Database accessible at http://research.amnh.org/herpetology/amphibia/index.html. Accessed on 08 July 2013.

Grant, T., E.C. Humphrey \& C.W. Myers (1997). The median lingual process of frogs: a bizarre character of Old World Ranoids discovered in South American dendrobatids. American Museum Norntates 3212: 1-40.

Hammer, Ø., D.A.T. Harper \& P.D. Ryan (2001). PAST: paleontological statistics software package for education and data analysis
Palaeontologia Electronica 4(1): 1-9.

Harris, R.J. (2001). A Primer for Multivariate Statistics - Third Edition. Lawrence Erlbaum Associates Publishers, London.

Huberty, C.J. \& S. Olejnik (2006). Applied MANOVA and Discriminant Analysis $-2^{\text {nd }}$ Edition. Hohn Wiley and Sons, N.J. 488pp.

Huelsenbeck, J.P. \& F. Ronquist (2001). MRBAYES: Bayesian inference of phylogenetic trees. Bioinformatics 17(8): 754-755; http://dx.doi. org/10.1093/bioinformatics/17.8.754

Kuramoto, M. \& S.H. Joshy (2003). Two new species of the genus Philautus (Anura: Rhacophoridae) from the Western Ghats, southwestern India. Current herpetology 22(2): 51-60.

Milne, I., F. Wright, G. Rowe, D.F. Marshal, D. Husmeier \& G. McGuire (2004). TOPALi: Software for automatic identification of recombinant 


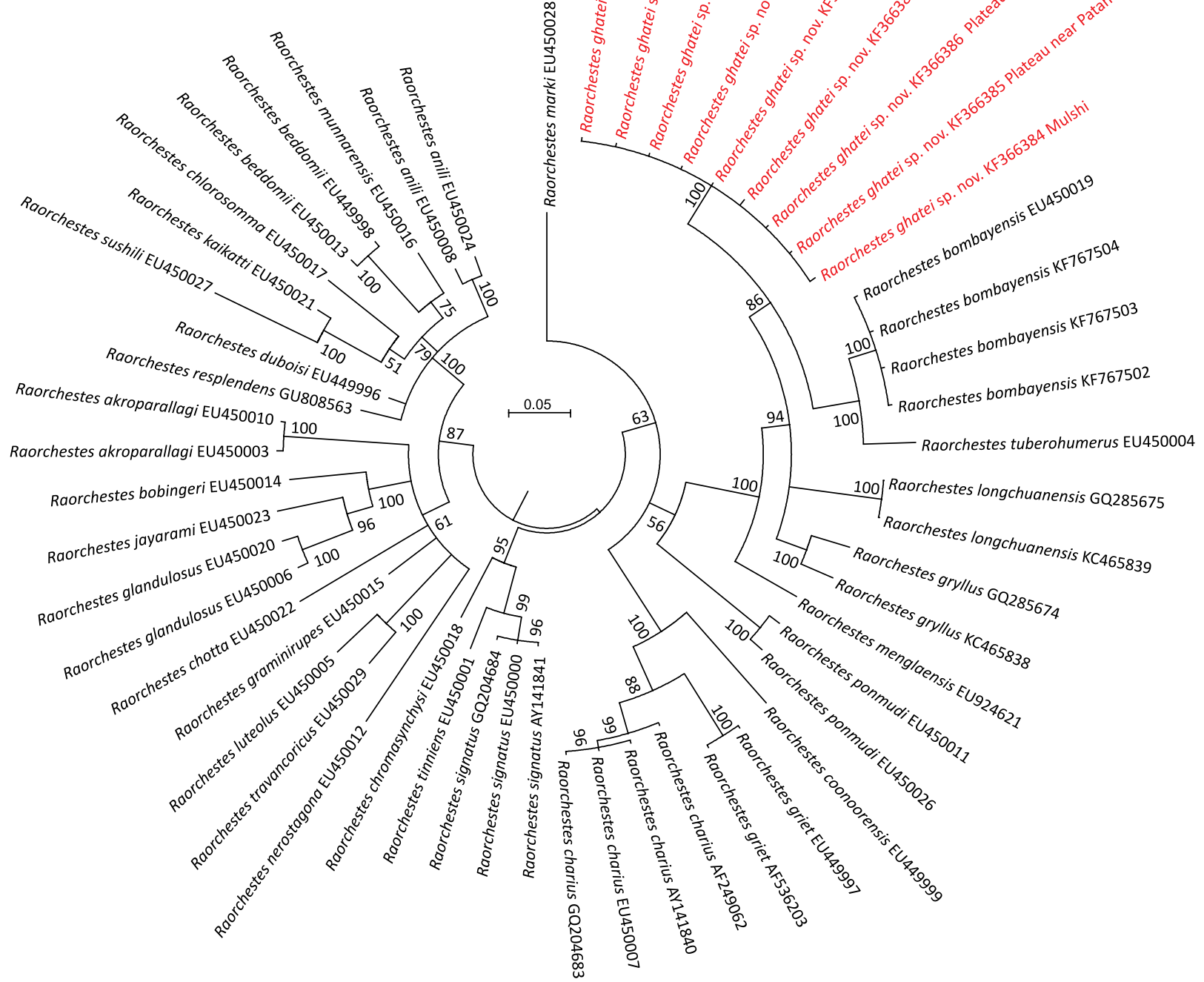

Appendix C. Unrooted phylogenetic tree of Raorchestes species using 16S rRNA gene based on Bayesian analysis. Posterior probabilities given at the nodes are in percentages.

sequences within DNA multiple alignments. Bioinformatics 20(11): 1806-1807; http://dx.doi.org/10.1093/bioinformatics/bth155

Orlov, N.L., N.A. Poyarkov, A.B. Vasilieva, N.B. Ananjeva, T.T. Nguyen, N. N. Sang \& P. Geissler (2012). Taxonomic notes on rhacophorid frogs (Rhacophorinae: Rhacophoridae: Anura) of southern part of Annamite Mountains (Truong Son, Vietnam), with description of three new species. Russian Journal of Herpetology 19: 23-64.

Padhye, A.D. \& H.V. Ghate (2002). An overview of amphibian fauna of Maharashtra state. Zoos' Print Journal 17(3): 735-740; http://dx.doi. org/10.11609/JoTT.ZPJ.17.3.735-40

Padhye, A.D. \& H.V. Ghate (2012). Amphibia. Zoological Survey of India, Fauna of Maharashtra, State Fauna Series 20(1): 239-246.

Palumbi, S.R., A. Martin, S. Romano, W.O. McMillan, L. Stice \& G. Grabowski (2002). The Simple Fool's Guide to PCR, Version 2.0 Department of Zoology and Kewalo Marine Laboratory, University of Hawaii, Honolulu, HI, 45pp. (Available online: http://palumbi. stanford.edu/SimpleFoolsMaster.pdf)

Pande, S., A. Padhye, P. Deshpande, A. Ponkshe, P. Pandit, A. Pawashe, S. Pednekar, R. Pandit \& P. Deshpande (2013). Avian collision threat assessment at 'Bhambarwadi Wind Farm Plateau' in northern Western Ghats, India. Journal of Threatened Taxa 5(1): 3504-3515; http://dx.doi.org/10.11609/JoTT.o3096.210

Posada, D. \& K.A. Crandall (2001). Selecting the best-fit model of nucleotide substitution. Systems Biology 50(4): 580-601; http:// dx.doi.org/10.1080/10635150118469

Potthoff, T. (1984). Clearing and staining techniques, pp. 35-37. In: Moser, H.G., W.J. Richards, D.M. Cohen, M.P. Fahay, A.W. Kendall, Jr. \& S.L. Richardson (eds.). Ontogeny and Systematics of Fishes. American Society for Ichthyology and Herpetology, Special Publication No. 1., 760pp. 

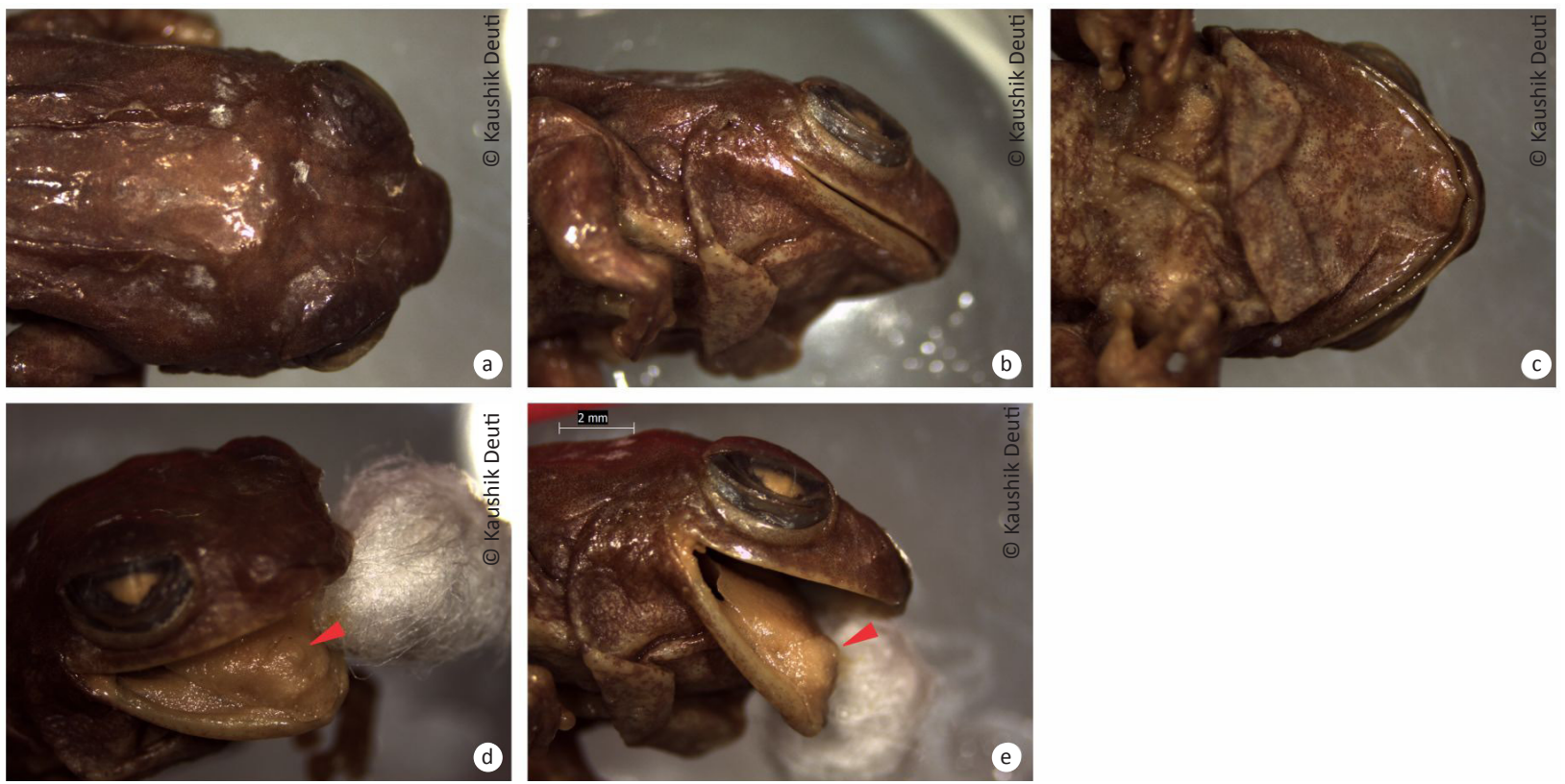

Appendix D. Head in the dorsal view (a), lateral view (b) and ventral view(c) of Raorchestes bombayensis holotype (ZSIC 18287). The papilla on the tongue is shown in (d) and (e).

Seshadri, K.S., K.V. Gururaja \& N.A. Aravind (2012). A new species of Raorchestes (Amphibia: Anura: Rhacophoridae) from mid-elevation evergreen forests of the southern Western Ghats, India. Zootaxa 3410: 19-34

Tamura, K., D. Peterson, N. Peterson, G. Stecher, M. Nei \& S. Kumar (2011). MEGA5: Molecular evolutionary genetics analysis using maximum likelihood, evolutionary distance, and maximum parsimony methods. Molecular Biology and Evolution 28: 27312739; http://dx.doi.org/10.1093/molbev/msr121

Yu, G., D. Rao, M. Zhang \& J. Yang (2009). Re-examination of the phylogeny of Rhacophoridae (Anura) based on mitochondrial and nuclear DNA. Molecular Phylogenetics and Evolution 50(3): $571-$ 579; http://dx.doi.org/10.1016/j.ympev.2008.11.023

Yu, G., M. Zhang \& J. Yang (2010). Generic allocation of Indian and Sri Lankan Philautus (Anura: Rhacophoridae) inferred from $12 \mathrm{~S}$ and $16 \mathrm{~S}$ rRNA genes. Biochemical Systematics and Ecology 38(3): 402-409; http://dx.doi.org/10.1016/j.bse.2010.03.011

Zachariah, A., K.P. Dinesh, E. Kunhikrishnan, S. Das, D.V. Raju, C. Radhakrishnan, M.J. Palot \& S. Kalesh (2011). Nine new species of frogs of the genus Raorchestes (Amphibia: Anura: Rhacophoridae) from southern Western Ghats, India. Biosystematica 5(1): 25-48.

\section{COMPARATIVE MATERIAL}

Raorchestes bombayensis: ZSIC 18287 (Holotype), BNHS 4589, BNHS 4418, BNHS 4419, WILD-13-AMP-230, WILD-13-AMP-231; AGCZRL-Amphibia-169, AGCZRLAmphibia-172, AGCZRL-Amphibia-173, AGCZRL-
Raorchestes tuberohumerous: BNHS 4193 (Holotype), BNHS 4194 (Paratype), BNHS 4512, BNHS 4590, BNHS 4498, BNHS 4499.

Raorchestes glandulosus: BNHS 4454, BNHS 1844-5

Raorchestes coonoorensis: BNHS 4444 (Holotype), BNHS 4446 (Paratype).

Raorchestes charius: BNHS 4424, BNHS 4036, BNHS 4422, BNHS 4421.

Raorchestes griet: BNHS 4457, BNHS 4464.

Raorchestes ponmudi: BNHS 4484, BNHS 4483.

Raorchestes luteolus: BNHS 4476, BNHS 4477, BNHS 4478.

Raorchestes gryllus: data from Orlav et al. (2012).

Raorchestes longchuanensis: photographs of holotype KIZ 74110046 available at http://www. dwbwg.org/museum_ky/museum_ky3/museum_ ky35/201208/t20120827_3634228.html

Raorchestes menglaensis: photographs of live specimen available at CallPhotos - http://calphotos. berkeley.edu/cgi/img_query?where-taxon=Raorche stes+menglaensis\&rel-taxon=begins+with\&wherelifeform=specimen_tag\&rel-lifeform=ne 